\title{
Analysis of trace metal distribution in plants with lab-based microscopic X-ray fluorescence imaging
}

Ana Mijovilovich ${ }^{1}$ (D), Filis Morina' ${ }^{1}$ Syed Nadeem Bokhari' ${ }^{1}$, Timo Wolff ${ }^{2}$ and Hendrik Küpper ${ }^{1,3^{*}}$ (D)

\begin{abstract}
Background: Many metals are essential for plants and humans. Knowledge of metal distribution in plant tissues in vivo contributes to the understanding of physiological mechanisms of metal uptake, accumulation and sequestration. For those studies, X-rays are a non-destructive tool, especially suited to study metals in plants.

Results: We present microfluorescence imaging of trace elements in living plants using a customized benchtop $X$-ray fluorescence machine. The system was optimized by additional detector shielding to minimize stray counts, and by a custom-made measuring chamber to ensure sample integrity. Protocols of data recording and analysis were optimised to minimise artefacts. We show that Zn distribution maps of whole leaves in high resolution are easily attainable in the hyperaccumulator Noccaea caerulescens. The sensitivity of the method was further shown by analysis of micro- $(\mathrm{Cu}, \mathrm{Ni}, \mathrm{Fe}, \mathrm{Zn})$ and macronutrients $(\mathrm{Ca}, \mathrm{K})$ in non-hyperaccumulating crop plants (soybean roots and pepper leaves), which could be obtained in high resolution for scan areas of several millimetres. This allows to study trace metal distribution in shoots and roots with a wide overview of the object, and thus avoids making conclusions based on singular features of tiny spots. The custom-made measuring chamber with continuous humidity and air supply coupled to devices for imaging chlorophyll fluorescence kinetic measurements enabled direct correlation of element distribution with photosynthesis. Leaf samples remained vital even after $20 \mathrm{~h}$ of $\mathrm{X}$-ray measurements. Subtle changes in some of photosynthetic parameters in response to the $\mathrm{X}$-ray radiation are discussed.

Conclusions: We show that using an optimized benchtop machine, with protocols for measurement and quantification tailored for plant analyses, trace metal distribution can be investigated in a reliable manner in intact, living plant leaves and roots. Zinc distribution maps showed higher accumulation in the tips and the veins of young leaves compared to the mesophyll tissue, while in the older leaves the distribution was more homogeneous.
\end{abstract}

Keywords: Micro X-ray fluorescence, Zinc, Hyperaccumulator, Micronutrients, Leaf age, Root, Arabidopsis halleri, Noccaea caerulescens, Glycine max, Capsicum annuum

\footnotetext{
*Correspondence: hendrik.kuepper@umbr.cas.cz

${ }^{1}$ Biology Centre of the Czech Academy of Sciences, Department

of Plant Biophysics \& Biochemistry, Institute of Plant Molecular Biology,

Branišovská 1160/31, 37005 Ceske Budejovice, Czech Republic

Full list of author information is available at the end of the article
}

\section{Background}

The transition metals $\mathrm{Cu}, \mathrm{Fe}, \mathrm{Mn}, \mathrm{Mo}, \mathrm{Ni}$ and $\mathrm{Zn}$ are essential micronutrients for plants, needed for proper function and structure of many proteins, redox reactions and regulation of transcription factors (e.g. Zn) (general plant reviews by Marschner [1]; Andresen et al.

c) The Author(s) 2020. This article is licensed under a Creative Commons Attribution 4.0 International License, which permits use, sharing, adaptation, distribution and reproduction in any medium or format, as long as you give appropriate credit to the original author(s) and the source, provide a link to the Creative Commons licence, and indicate if changes were made. The images or other third party material in this article are included in the article's Creative Commons licence, unless indicated otherwise in a credit line to the material. If material is not included in the article's Creative Commons licence and your intended use is not permitted by statutory regulation or exceeds the permitted use, you will need to obtain permission directly from the copyright holder. To view a copy of this licence, visit http://creativeco mmons.org/licenses/by/4.0/. The Creative Commons Public Domain Dedication waiver (http://creativecommons.org/publicdomain/ zero/1.0/) applies to the data made available in this article, unless otherwise stated in a credit line to the data. 
[2]; photosynthesis-oriented review by Yruela [3]). In addition, micronutrients are involved in plant defence responses against abiotic (extreme weather conditions) and biotic stress (pathogens) [2, 4]. Requirements for micronutrients are species-specific, but also vary in relation to plant age, organ and tissue level. Excessive accumulation of micronutrients, however, is detrimental for plants [5].

Plants have developed different strategies for regulating metal homeostasis, which divide them into three categories: excluders, indicators and hyperaccumulators [6]. Excluders keep a constant concentration in the shoots by restricting uptake and enhancing efflux of excess metals. Indicators accumulate metals in the shoots, commensurate to their concentration in the soils. Hyperaccumulators actively accumulate metals even in metal-deficient soils, and metal content in the shoots may reach up to several percent of dry matter; e.g. $1 \%$ is the lower threshold for defining a Zn-hyperaccumulator (review by Leitenmaier and Küpper [7]). The same species might belong to different categories for different metals. This is the case of Noccaea caerulescens, which hyperaccumulates $\mathrm{Zn}$ and $\mathrm{Cd}$ but not $\mathrm{Cu}[8,9] . N$. caerulescens has a different strategy to tolerate excess $\mathrm{Cu}$ [9] than $\mathrm{Zn}$ and $\mathrm{Cd}[10]$.

Besides their essential role in metabolism of all organisms, in hyperaccumulating plants metals are a part of the defence mechanism against herbivores and pathogens [7, 11-15]. In non-accumulator organisms, metals are involved in immunity as well, as it is well-known from animals, but at least for Fe it was also already demonstrated in plants [4].

To be able to understand the role of micronutrients in plant stress response but also in growth and development, differential accumulation and requirements within the same organ, and within different tissues have to be considered (reviews by Zhao et al. [16]; van der Ent et al. [17]). For example, cellular metal distribution in the leaves of $N$. caerulescens has been analysed using energy dispersive X-ray microanalysis (EDXMA) in shock-frozen hydrated samples, showing that most of the $\mathrm{Zn}$ is accumulated in large epidermal storage cells [18]. The distribution of Cd in N. caerulescens has been determined by autoradiography to avoid the interference of $\mathrm{K}$ in the L-edge of Cd in X-ray analysis like EDXMA [19]. Cd was found in the whole leaf but mostly concentrated in the edge. An important question is if any redistribution of metals occurs with aging. In N. caerulescens, more $\mathrm{Zn}$ was found in mature leaves than in young leaves $[18,20]$. Investigating $\mathrm{Zn}$ metabolism and homeostasis in hyperaccumulators like $N$. caerulescens benefits from the ideal signal/noise ratio for the accumulated metal. Nevertheless, not all processes can be studied in hyperaccumulator models so that non-accumulators like crop plants need to be studied as well (reviews by Leitenmaier and Küpper [7]; Andresen et al. [2]; Krämer [21]).

$\mathrm{X}$-ray based imaging methods are more challenging in non-accumulators because of the very low concentrations of the most interesting trace metals such as $\mathrm{Fe}, \mathrm{Cu}$, $\mathrm{Mn}$ and $\mathrm{Zn}$. With most standard benchtop machines, trace metals in low concentrations are not accessible and so far there have been no data on micronutrient detection in the leaves using such machine. A recent publication demonstrated $\mathrm{Zn}$ visualization in a "primed" seed. However, this was achieved only by immersing the seeds in a very high $\mathrm{Zn}$ concentration $\left(1000 \mathrm{mg} \mathrm{kg}^{-1}\right.$ ) [22] (all concentrations in parts per million $\left(\mathrm{mg} \mathrm{kg}^{-1}\right)$ ). Using an earlier version of the machine presented in this work, but with a smaller detector area and unshielded, Ramos et al. [23] obtained unquantified images of elemental distribution in soybean seeds (with $\mathrm{Zn}$ content ranging from 10th to 100th of $\mathrm{mg} \mathrm{kg}^{-1}$ ). In this case, a single detector with a smaller area $\left(30 \mathrm{~mm}^{2}\right)$ was sufficient to obtain structural resolution due to the big size of the seed tissues (in the range of $\mathrm{mm}$ ).

For synchrotron studies, whole plant organs like entire leaves or roots are gigantic objects requiring unfeasible amount of beamtime. Therefore, synchrotron X-ray studies are restricted to small objects/sections. Benchtop machines open the possibility to study the whole object. Furthermore, studies on living samples at synchrotrons are problematic because synchrotrons lack the infrastructure for conducting sophisticated plant experiments such as long-term metal treatments. In addition, to obtain insight into long-term element re-distributions as a result of ontogenesis, abiotic or biotic stress, it is necessary to perform several measurements. This is not possible at synchrotrons due to the beamtime limitation. On the other hand, lab-based benchtop machines situated in plant research institutes enable analysis of plants from all types of experiments in vivo. Several groups have endeavored in developing benchtop micro-X-ray fluorescence $(\mu \mathrm{XRF})$, either with self-made set-ups $[22,24]$ or commercial devices [23]. The main advantage of $\mu \mathrm{XRF}$ to study mineral nutrition in plants over mass spectroscopic methods in that it is non-destructive.

In this work we demonstrate the use of a novel optimized benchtop $\mu$ XRF system with a custom-designed measuring chamber. It enabled visualization of trace metal distribution in living leaf and root samples. Moreover, the system can be used not only for studying metalhyperaccumulators but also for non-accumulator crop species grown under environmentally relevant conditions. We discuss the difficulties in measuring samples with topography, the choice of filters, focusing problems and possible artifacts as well as the choice of 
standards for most accurate quantification, which were compared to inductively coupled plasma mass spectrometry (ICP-MS) data. The application example shows the $\mathrm{Zn}$ accumulation pattern along the leaf development of $N$. caerulescens, metal distribution in the leaves of Capsicum annuum (pepper) and in the root hairs of Glycine $\max$ (soybean). The quantification was done with standards that match the tissue thickness. Leaf integrity after $20 \mathrm{~h}$ of measurements (up to $600 \mathrm{~ms}$ on a single spot) was evaluated by measuring photosynthetic parameters. In our work we show how the improved spatial resolution (twofold) and detection efficiency (with about fourfold more detector area) results in cellular resolution in leaves, and tissue resolution in roots, with a much lower dose reducing the chance of radiation damage. The presented system allows studying metal uptake and distribution in vivo, at trace concentrations, without artifacts caused by sample manipulation. Metal distribution can be directly related to primary photochemical reactions and other physiological processes and plant stress responses, which are important for ecological and agricultural studies.

\section{Methods}

\section{Plant growth}

Alpine Penny-cress (Noccaea caerulescens (J.Presl \& C.Presl) F.K.Mey=formerly Thlaspi caerulescens J.Presl \& C.Presl), 'Ganges' ecotype, was germinated as described earlier [25] and then grown hydroponically for 12 weeks before starting to harvest the leaves for the experiments. The nutrient solution HHNS ("hyperaccumulator hydroponic nutrient solution") consisted of $1000 \mu \mathrm{mol} \mathrm{L} \mathrm{L}^{-1} \mathrm{Ca}\left(\mathrm{NO}_{3}\right)_{2}, 500 \mu \mathrm{mol} \mathrm{L}{ }^{-1} \mathrm{MgSO}_{4}$, $50 \mu \mathrm{mol} \mathrm{L}{ }^{-1} \mathrm{~K}_{2} \mathrm{HPO}_{4}, 100 \mu \mathrm{mol} \mathrm{L}{ }^{-1} \mathrm{KCl}, 10 \mu \mathrm{mol} \mathrm{L}{ }^{-1}$ $\mathrm{H}_{3} \mathrm{BO}_{3}, 0.1 \mu \mathrm{mol} \mathrm{L}{ }^{-1} \mathrm{MnSO}_{4}, 0.2 \mu \mathrm{mol} \mathrm{L} \mathrm{L}^{-1} \mathrm{Na}_{2} \mathrm{MoO}_{4}$, $0.1 \mu \mathrm{mol} \mathrm{L}-1 \mathrm{CuSO}_{4}, 0.5 \mu \mathrm{mol} \mathrm{L}^{-1} \mathrm{NiSO}_{4}, 20 \mu \mathrm{mol} \mathrm{L}^{-1}$ $\mathrm{Fe}(\mathrm{III})$-EDDHA (Fe(III)-ethylenediamine-di(o-hydroxyphenylacetic acid), and $100 \mu \mathrm{mol} \mathrm{L}^{-1} \mathrm{ZnSO}_{4}$ as described before [25]. Plants were grown in a greenhouse with automatic ambient light supplementation by a 1:1 mix of cool white and warm white LEDs (Photon System Instruments, Brno, Czech Republic) to achieve a 16 h sinusoidal light cycle with $500 \mu \mathrm{mol} \mathrm{m}^{-2} \mathrm{~s}^{-1}$ photon flux density. The temperature was regulated to max. $25^{\circ} \mathrm{C}$ during the day. Leaves from three plants were sampled from five different points of the rosette covering different stages of development: from the young leaves in the apical meristem rosette down to the elderly, but not senescent, leaves. The harvesting strategy along the rosette is shown in Fig. 1.

Soybean (Glycine max (L.) Merr, cultivar 'Galina') seeds were germinated on a moistened mixture of perlite and vermiculite (1:3) in the dark at $25^{\circ} \mathrm{C}$ to promote

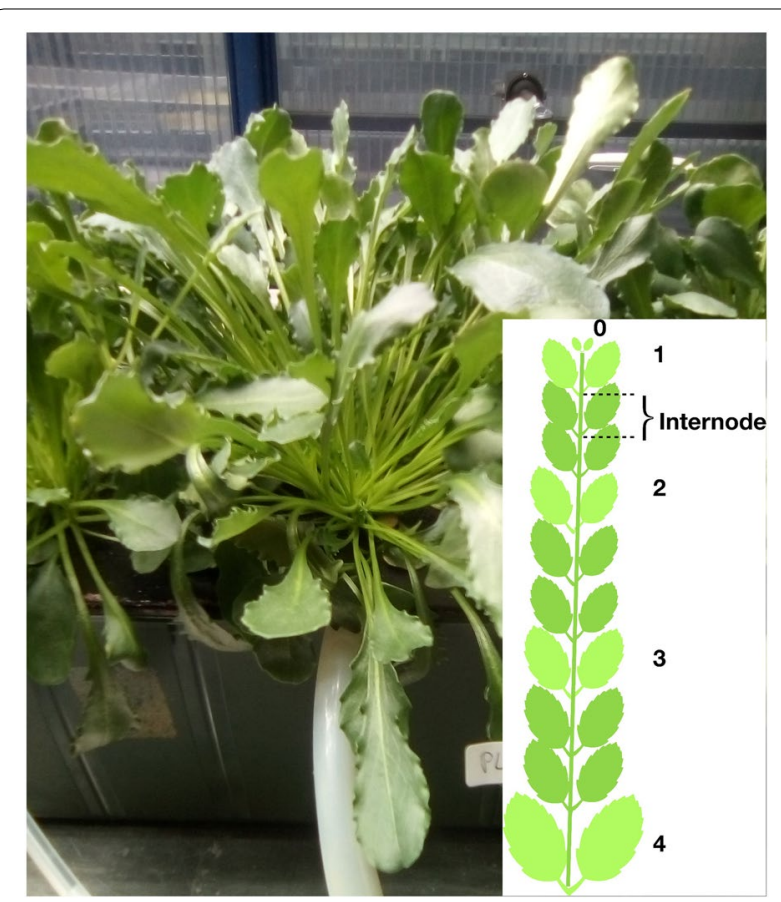

Fig. 1 Images of one of the $N$. caerulescens plants at the moment of harvest (12 weeks after germination), and the harvesting strategy along one plant shoot branch. Please note that in the scheme the internodes are shown strongly elongated to visualize better the positions of the leaves. The internodes were counted by carefully opening the plant from the top and labelling the leaves. Since in $N$. caerulescens the internodes are tiny, it is not possible to see them in the picture

radicle development (similarly to e.g. Graham [26]). After 3 days they were transferred to the phytochamber with a sinusoidal light cycle (maximum $500 \mu \mathrm{mol} \mathrm{m}{ }^{-2} \mathrm{~s}^{-1}$, provided by 8 channels of LEDs to simulate sunlight; Photon System Instruments, Brno, Czech Republic), temperature cycle $\left(25{ }^{\circ} \mathrm{C}\right.$ at noon and $18{ }^{\circ} \mathrm{C}$ at night) and moisture cycle $(40 \%$ relative humidity in the afternoon, $60 \%$ in the morning before onset of light). Ten days old seedlings (four plants per pot) were transferred to modified $1 / 2$ strength of the HHNS [10, 25] consisting of $1000 \mu \mathrm{mol} \mathrm{L}^{-1} \mathrm{Ca}\left(\mathrm{NO}_{3}\right)_{2}, 250 \mu \mathrm{mol} \mathrm{L}^{-1} \mathrm{MgSO}_{4}$, $250 \mu \mathrm{mol} \mathrm{L}{ }^{-1} \mathrm{~K}_{2} \mathrm{HPO}_{4}, 50 \mu \mathrm{mol} \mathrm{L}{ }^{-1} \mathrm{KCl}, 10 \mu \mathrm{mol} \mathrm{L}{ }^{-1}$ $\mathrm{H}_{3} \mathrm{BO}_{3}, 0.5 \mu \mathrm{mol} \mathrm{L}^{-1} \mathrm{MnSO}_{4}, 0.2 \mu \mathrm{mol} \mathrm{L}{ }^{-1} \mathrm{Na}_{2} \mathrm{MoO}_{4}$, $0.3 \mu \mathrm{mol} \mathrm{L}^{-1} \mathrm{CuSO}_{4}, 1 \mu \mathrm{mol} \mathrm{L}^{-1} \mathrm{ZnSO}_{4}, 0.5 \mu \mathrm{mol} \mathrm{L}^{-1}$ $\mathrm{NiSO}_{4}$ and $20 \mu \mathrm{mol} \mathrm{L}{ }^{-1} \mathrm{Fe}$ (III)-EDDHA (Fe(III)-ethylenediamine-di(o-hydroxyphenylacetic acid). The nutrient solution was continuously renewed with a flow rate of $150 \mathrm{~mL}$ day $^{-1}$ plant $^{-1}$, which was increased to $250 \mathrm{~mL}$ day $^{-1}$ plant $^{-1}$ after 1 week of treatment as described before [25]. After 3 weeks, the second root branch from the top was taken for analysis, and after rinsing in $\mathrm{Zn}$-deficient HHNS the middle part of the root 
branch was placed in the measuring chamber filled with Zn-HHNS.

Haller's rockcress (Arabidopsis halleri (L.) O'Kane \& Al-Shehbaz) plants were grown on soil (mix of $70 \%$ commercial peat-free gardening soil and $30 \%$ sand) with the same light and temperature conditions as described for N. caerulescens.

Chili pepper (Capsicum annuum, cultivar 'Kozí Roh') plants were grown on soil (mix of $70 \%$ commercial peatfree gardening soil and 30\% sand) under natural daylight and room temperature. Young-mature pepper leaves (just having reached the final size of 3-4 $\mathrm{cm}$ ) were harvested from approximately 3 to 4 years-old plants.

\section{Determination of total metal concentration with ICP-MS}

For total metal concentration the lyophilized $N$. caerulescens and C. annuum leaves (about $30 \mathrm{mg}$ ) were digested in glass tubes with $0.5 \mathrm{~mL}$ of a mixture of $85 \mathrm{~L} 100 \mathrm{~L}^{-1}$ of concentrated (70\%) $\mathrm{HClO}_{4}$ (Suprapur ${ }^{\circledR}$ grade, Carl Roth,

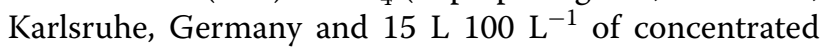
(69\%) $\mathrm{HNO}_{3}$ (Ultrapur ${ }^{\circledR}$ grade, Carl Roth, Karlsruhe, Germany) following the protocol of Zhao et al. [27]. Glycine max roots (four plants per pot) were washed twice with double distilled water $\left(\mathrm{ddH}_{2} \mathrm{O}\right)$, tap dried and homogenized in liquid nitrogen. Following lyophilization, about $30 \mathrm{mg}$ of the pooled root samples were used for digestion in three technical replicates.

The glass tubes were uniformly heated using a Fuji PXG4 Thermoblock (AHF Analysentechnik AG, Tübingen, Germany). A program was used for ramping the temperature of the acid mixture to $220^{\circ} \mathrm{C}$ for $4 \mathrm{~h}$. The acid mixture was then heated at $220{ }^{\circ} \mathrm{C}$ for another hour to dry the digest from acid contents. The digest was then cooled to room temperature and $0.5 \mathrm{~mL}$ of $5 \%$ $\mathrm{HCl}$ (Ultrapur ${ }^{\circledR}$ grade, Carl Roth, Karlsruhe, Germany) was added to each test tube. Afterwards the glass tubes were heated to $90{ }^{\circ} \mathrm{C}$ for $1 \mathrm{~h}$ to obtain clear solutions. The final volume was made to $1.5 \mathrm{~mL}$ with $\mathrm{ddH}_{2} \mathrm{O}$ and stored in $2 \mathrm{~mL}$ microcentrifuge vials. Sample solutions were diluted $7000 \times$ with $0.2 \% \mathrm{HNO}_{3}$. Indium was added as internal standard at $1 \mu \mathrm{g} / \mathrm{L}$ to each test solution. The Inductively Coupled Plasma (ICP) multi-element standard solution VI (Merck KGa, Darmstadt, Germany) was used for preparation of several ranges of calibration points. The solution was chosen as standard since the matrix effect was negligible for the quantification of analytes in plant digests. The sector field Inductively Coupled Plasma Mass Spectrometry (ICP-sfMS) Element XR-2 with jet interface (Thermo Fisher Scientific, Bremen, Germany) was used for the elemental analysis of the plant digests. The instrument was optimally tuned to reduce the potential interferences by choosing low, medium and high resolutions (similar to Andresen et al.,
2013 [28]). Oxide formation rate was acceptably low as monitored by $\mathrm{CeO}^{+} / \mathrm{Ce}^{+}$. The typical operating conditions of the ICP-sfMS were: RF power: $1250 \mathrm{~W}$, spray chamber temperature: $2{ }^{\circ} \mathrm{C}$, oxide ratio $\mathrm{CeO}^{+} / \mathrm{Ce}^{+}: 1.0$ $1.2 \%$, Doubly charged $\mathrm{Ce}^{2+} / \mathrm{Ce}^{+}: 1.0-1.2 \%$, auxiliary Gas: $0.8 \mathrm{~L} \mathrm{~min}^{-1}$, Sample gas flow: $1.20 \mathrm{~L} \mathrm{~min}^{-1}$ (variable), Cool gas: $16 \mathrm{~L} \mathrm{~min}^{-1}$, Extraction lenses: $-2000 \mathrm{~V}$, Low resolution: 300, Medium resolution: 4000, High resolution: 10,000, Interface cones: $\mathrm{Ni}$ sample and $\mathrm{H}$-skimmer cones. In order to avoid contaminations, the ICP-MS is located in a cleanroom with air filtration. All measurements follow a "metal free" protocol, proved in earlier works involving metal deficiency [29], which forbids metal tools and is using Polytetrafluoroethylene (PTFE) tools and vials made from PFA (Perfluoroalkoxy alkanes; Savillex, Eden Prairie, MN, USA) because of their low metal contamination.

\section{Mounting of intact samples (leaves and roots) for in vivo measurements}

For all in vivo measurements (chlorophyll fluorescence kinetics and $\mu \mathrm{XRF}$ ), samples were mounted in a modified version of the measuring chamber that was originally developed for fluorescence kinetic measurements [25]. The new version of the chamber is shown in Fig. 2. Compared to the previously published version of the chamber, the distance from the sample to the highest point of the chamber had to be drastically reduced because of the short working distance of the benchtop system; when in focus it leaves about $6 \mathrm{~mm}$ space between the crash protection plate and the surface of the sample. Therefore, the inlets and outlets for air/nutrient media of the chamber had to be moved from the top to the side, the lid had to be made thinner, and the toric seal (O-ring) holding the leaf assembly had to be moved directly to the lower side of the lid. Finally, the glass window was replaced by a window made of $80 \mu \mathrm{m}$ thick laser printer foil to diminish the absorption of X-rays.

Leaves were mounted by putting them onto the measuring chamber, then placing a cotton pad on top, then a plastic disc (with holes for aeration) for gently pressing them. The whole assembly was finally covered with a fine $(5 \mu \mathrm{m}$ pore size) nylon mesh from below, which was stretched by an O-ring (Fig. 2 and Additional file 1: Figure S1). The petiole of the leaf was put into a small water-filled Petri dish in the bottom of the chamber, to keep the leaf hydrated. The chamber was flushed with air. The air was saturated with water by making it bubble in a flask filled with water with an aquaria pump (TetraTec APS 300, Tetra, a Spectrum Brands Company, Melle, Germany) and connected with PTFE tubing to the inside of the $\mu$ XRF machine enclosure and to the measuring chamber inside (Fig. 3). 


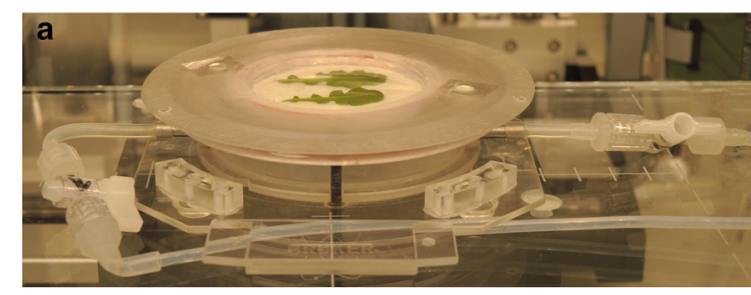

b

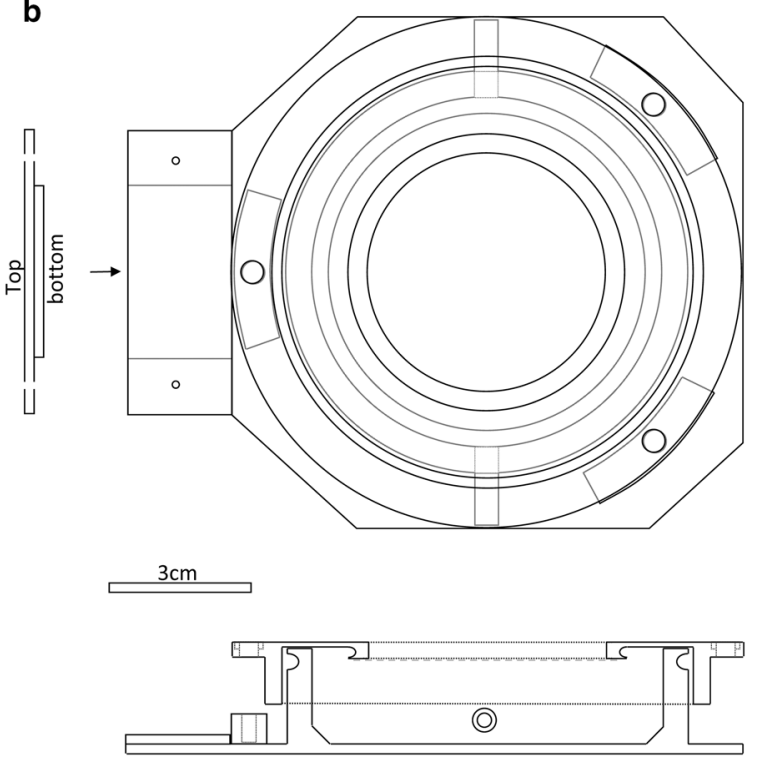

Fig. 2 Measuring chamber used for the $\mu$ XRF and chlorophyll fluorescence kinetic measurements of living samples. a Photo, $\mathbf{b}$ drawing

Root sections were mounted by putting them in nutrient solution without $\mathrm{Zn}$ onto the window of the chamber. Afterwards, a piece of cellophane previously boiled and washed several times in $\mathrm{ddH}_{2} \mathrm{O}$ to remove any adhering particles was stretched over the roots by the O-ring. The chamber was filled with the same nutrient solution, which was continuously renewed during the measurement via a peristaltic pump (Ismatec REGLO ICC Digital Peristaltic Pump, Cole-Parmer GmbH, Wertheim, Germany) attached to the PTFE tubing outside of the hutch of the $\mu$ XRF machine (see Fig. 3).

\section{Chlorophyll fluorescence kinetic measurements}

Chlorophyll fluorescence kinetics (for more information see Genty et al. [30]; Baker [31]; Maxwell and Johnson [32]; Stirbet and Govindjee [33]) was measured using a macroscopic fluorescence imaging system with a newly developed ultrafast camera and software for direct imaging of fast fluorescence transients (Photon Systems Instruments (PSI), Brno, Czech Republic). All technical properties of the instrument are described in a recent publication [34]. Measurements of fast chlorophyll fluorescence transient (OJIP) induction kinetics were conducted using a custom-made protocol on darkadapted leaves as described by Küpper et al. [34]. The frame period was $250 \mu \mathrm{s}$, the shutter opening (measuring flash length) was $100 \mu$ s and the supersaturating pulses were $4000 \mu \mathrm{mol} \mathrm{m}{ }^{-2} \mathrm{~s}^{-1}$. The definitions of OJIP parameters as described by [33] were used for calculating maps of OJIP parameters: $\Phi_{\text {Po }}$-maximum quantum yield of primary PSII photochemistry, $\Phi_{\mathrm{ET} 2 \mathrm{o}}$ - quantum yield of the electron transport flux from $\mathrm{Q}_{\mathrm{A}}$ to $\mathrm{Q}_{\mathrm{B}}$, and $\Phi_{\mathrm{RE} 1 \mathrm{o}}-$ quantum yield of the electron transport flux until PSI electron acceptors. Quantum yield refers to stable charge separation or oxygen evolution divided by the number of absorbed photons, or the efficiency of photochemistry (Kalaji et al. [35] and references therein).

Measurements of slow chlorophyll fluorescence induction and quenching kinetics were done according to the protocol described by Küpper et al. [25] but with adaptations for the new measuring device as described by Küpper et al. [34]. In summary, a $1000 \mathrm{~ms}$ flash of supersaturating light $\left(4000 \mu \mathrm{mol} \mathrm{m} \mathrm{m}^{-2} \mathrm{~s}^{-1}\right)$ for $\mathrm{F}_{\mathrm{m}}$ was followed by $90 \mathrm{~s}$ of darkness, after which $\mathrm{F}_{0}$ was measured for $5 \mathrm{~s}$. Then, $100 \mathrm{~s}$ of actinic light were applied to analyse the Kautsky induction, and finally $100 \mathrm{~s}$ of measurement with no actinic light were used to measure dark relaxation and $\mathrm{F}_{0}^{\prime}$. During the actinic light exposure $\left(100 \mu \mathrm{mol} \mathrm{m} \mathrm{m}^{-2} \mathrm{~s}^{-1}\right)$ and in the dark relaxation period, $600 \mathrm{~ms}$ supersaturating flashes were applied for analysis of photochemical $\left(\Phi_{\mathrm{PSII}^{-}}\right.$ operating efficiency of PSII) and non-photochemical quenching $\left(\mathrm{NPQ}=\left(\mathrm{F}_{\mathrm{m}}-\mathrm{F}_{\mathrm{m}}^{\prime}\right) / \mathrm{F}_{\mathrm{m}}\right)$. A typical Chl fluorescence trace is shown in Additional file 2: Figure S2.

Chlorophyll fluorescence kinetics of pepper leaves was measured immediately before and immediately after the $\mu$ XRF measurements, which lasted about $20 \mathrm{~h}$. OJIP ( $\Phi_{\text {Po }}$, $\Phi_{\text {ET2o }}$ and $\left.\Phi_{\text {RE1o }}\right)$ and Kautsky parameters $\left(\Phi_{\text {PSII }}\right.$ and NPQ) were compared between the X-ray exposed area and adjacent, bordering part of the leaf of the same size as the exposed area. During the $\mu \mathrm{XRF}$ measurements, the camera light was switched off, but the measuring hutch was illuminated.

\section{X-ray microfluorescence scanning}

$\mathrm{X}$-ray fluorescence was measured with a customised M4 TORNADO system (Bruker Nano GmbH, Berlin, Germany). This machine was equipped with two XFlash ${ }^{\circledR}$ silicon drift detectors (type SDD VH50P) able to cope with count rates as high as 310,000 counts per second (cps) with an energy resolution $<145 \mathrm{eV}(\mathrm{Mn} \mathrm{K \alpha})$ according to manufacturer's parameters (Bruker Nano $\mathrm{GmbH}$, Berlin, Germany). In this work all measurements were done with the $\mathrm{Rh}$ tube with a $0.1 \mathrm{~mm}$ Be window (Incoatec $\mathrm{GmbH}$, Geesthacht, Germany) and polycapillary optics (IFG Institute for Scientific Instruments, 


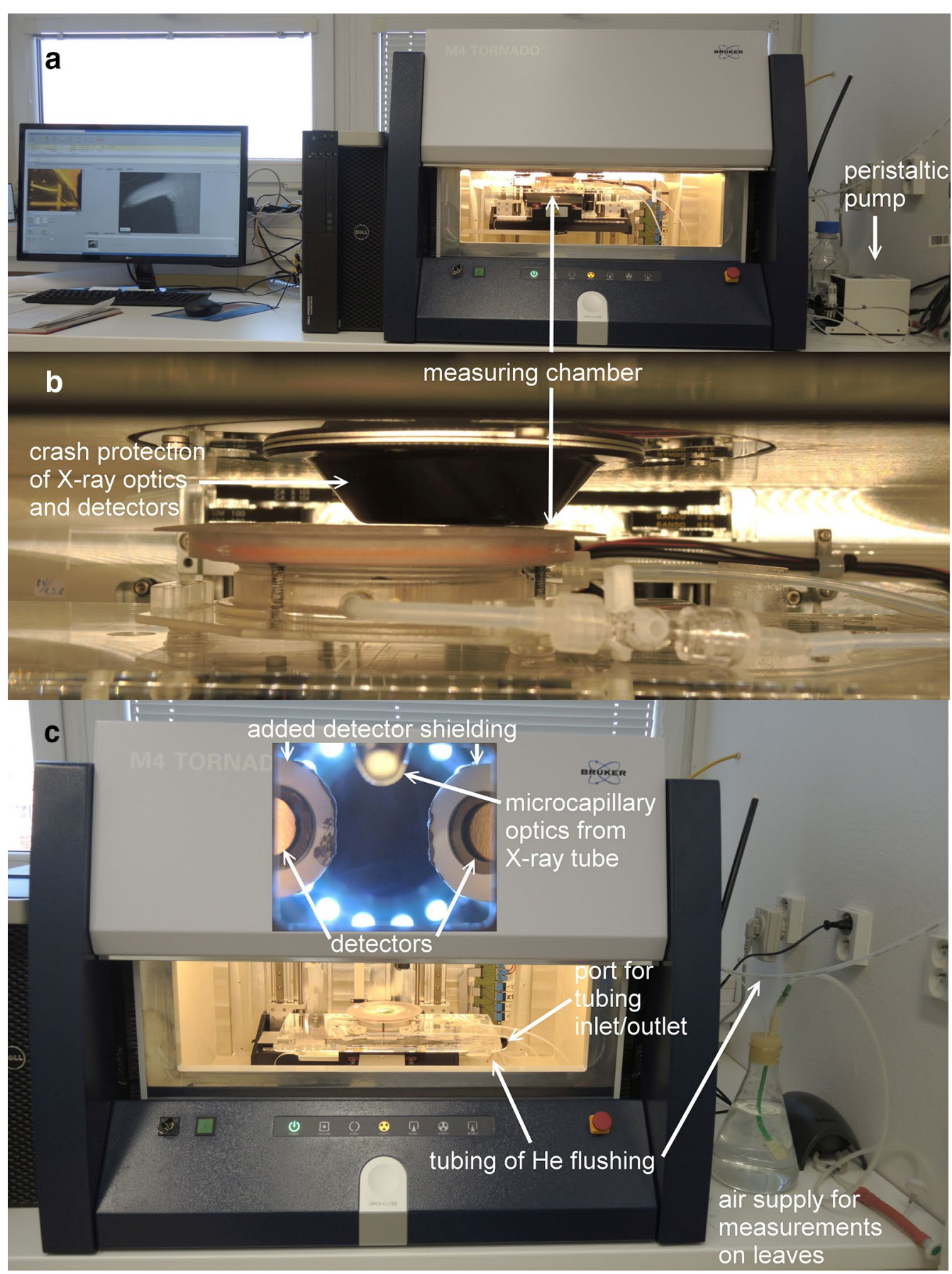

Fig. 3 Photos of the $\mu$ XRF system configuration. a Configuration of the whole system, as set up for measurements on roots i.e. with peristaltic pump for liquid media. $\mathbf{b}$ Close-up view of the in vivo measuring chamber in focus position. c Configuration of the system as set up for measurements on leaves i.e. with air supply

Berlin, Germany). It was operated at $50 \mathrm{kV}$ and $600 \mu \mathrm{A}$. The polychromatic incoming flux of the X-ray tube spans over $40 \mathrm{keV}$ with the structure shown in the Additional file 3: Figure S3. All photons with energy above the chosen absorption edge will not be equally absorbed, but with an energy dependent cross section [36]. This means that the beam is not equivalent to a monochromatic beam with the same flux (photons/second). The measuring hutch and the sample stage with the in vivo measuring chamber mounted on it are shown in Fig. 3. A filter 
composed of $100 \mu \mathrm{m}$ of $\mathrm{Al}$ and $25 \mu \mathrm{m}$ of $\mathrm{Ti}$ was used to flatten the bremsstrahlung in the energy region of the transition metals. A polycapillary lens was used to focus the photons with the highest transmission at $9 \mathrm{keV}$ [37]. Besides the measurement of the transmission of a polycapillary lens shows little variation in the range 5-10 eV (see Fig. 1 in Wolff et al. [38]). The polycapillary lens provided a beam spot size of about $15 \mu \mathrm{m}$ for the $\mathrm{Mn}$ $\mathrm{K} \alpha$ line. The machine was customized for the needs of this project in several ways: (1) At request of the authors the machine was specially fitted with a multilayer mask (Bruker Nano GmbH, Berlin, Germany) on the detectors to reduce spurious counts of $\mathrm{Ni}, \mathrm{Cu}$ and $\mathrm{Zn}$, resulting in a clean spectrum of $\mathrm{Zn}$ and $\mathrm{Cu}$, with a few \% contamination of Ni (Additional file 4: Figure S4) [39]. (2) In order to be able to measure samples in vivo, a PTFE tubing was inserted that transports water-saturated air or nutrient solution through the plant measuring chamber. (3) Since the measuring chamber cannot be operated in vacuum, a line for He flushing (inlet and outlet) was installed for enhancing the measurement of low- $\mathrm{Z}$ elements. The fluorescence maps were collected for a total time of 3-25 ms per pixel for N. caerulescens, $150 \mathrm{~ms}$ for A. halleri and 480-720 ms for pepper and soybean.

\section{Resolution of the X-ray microfluorescence scanning}

When measuring elements from the soft to the hard $\mathrm{X}$-ray range, it is important to remind that the spot size is energy dependent [37] with a term that is inversely proportional to the energy [24]. Smaller spot sizes are obtained for increasing energies. The size of the spot for transition metals was about $15 \mu \mathrm{m}$. To know in how far the spot size is influenced by primary emission filters, the edge of an aluminium foil was scanned without and with an Al-Ti filter (Additional file 5: Figure S5). This test, which also included the absorption and reflectivity effects, showed that the effect on the resolution of the polychromatic X-ray source was negligible.

\section{Standards for quantification}

The foil standards for calibration were made to include all elements of interest for the current study, with the concentration ratios approximately (order of magnitude) matching the plant samples. Foil standards matching the thickness of the plant leaves were made by dissolving polyvinyl alcohol (PVA, Ultimaker, Geldermalsen, The Netherlands) in double distilled water $(20 \% \mathrm{w} / \mathrm{v})$. PVA was chosen as a matrix because among available polymers it (a) resembles an organic matrix quite well with its formula $\left[\mathrm{CH}_{2} \mathrm{CH}(\mathrm{OH})\right]_{\mathrm{n}}$, (b) it is very well water soluble and therefore homogenously miscible with the metal solutions until dryness. To this solution, $\mathrm{Ca}\left(\mathrm{NO}_{3}\right)_{2}$ and $\mathrm{KCl}$ were added from $100 \mathrm{mmol} \mathrm{L}^{-1}$ stock solutions, $\mathrm{ZnSO}_{4}$ was added from a $1 \mathrm{~mol} \mathrm{~L}^{-1}$ stock solution, Cu-EDTA, FeNa-EDTA, Mn-EDTA and Ni-EDTA were added from $10 \mathrm{mmol} \mathrm{L}^{-1}$ stock solutions. The residual volume was filled with water. The resulting final concentrations in the standard stock were: $10 \%$ PVA, $0.5 \mathrm{mmol} \mathrm{L}^{-1} \mathrm{Cu}$ and $\mathrm{Mn}, 1 \mathrm{mmol} \mathrm{L}^{-1} \mathrm{Fe}, \mathrm{Na}$ and $\mathrm{Ni}, 5 \mathrm{mmol} \mathrm{L}^{-1} \mathrm{Ca}$ and $\mathrm{K}$, $5.5 \mathrm{mmol} \mathrm{L}^{-1} \mathrm{Cl}, 11.5 \mathrm{mmol} \mathrm{L}^{-1} \mathrm{~S}, 100 \mathrm{mmol} \mathrm{L}^{-1} \mathrm{Zn}$ (for $N$. caerulescens; otherwise $0.5 \mathrm{mmol} \mathrm{L}^{-1} \mathrm{Zn}$ ). The mixture was diluted with 10\% PVA to yield standards of different concentrations. The standards were pipetted into a 3D-printed grid of $1 \times 1 \mathrm{~cm}^{2}$ squares, and left to dry in a cleanroom. Foil layers were stuck to reproduce 200 and $400 \mu \mathrm{m}$ thickness. The metal content of the foil was determined with ICP-MS. Standards for root samples were polyimide tubings of a diameter close to the root of interest, filled with aqueous solutions of all elements of interest plus $20 \%$ glycerol to bring the content of light elements $(\mathrm{C}, \mathrm{H}, \mathrm{O})$ close to a plant sample.

\section{Quantification of a N. caerulescens leaf $\mu$ XRF maps with empirical standards}

The fluorescence maps were processed using the software provided with the machine. The fitting method was created with the Xmethod software [40] (Bruker Nano $\mathrm{GmbH}$, Berlin, Germany). The background is determined mathematically by a peak stripping approach that gives a flat background after several cycles. The data was calibrated with the mentioned foil standards to a straight line without offsets. This fully empirical method relies on the assumption that the foil standard resembles the sample matrix as well as the sample thickness. Two different sets of standards were used to match the thickness of about $200 \mu \mathrm{m}$ for young leaves (at position $\mathbf{0}$ ) and $400 \mu \mathrm{m}$ for young mature to fully mature leaves $(\mathbf{1}-\mathbf{4})$ of $N$. caerulescens, with thicknesses measured with a digital caliper (model Workzone, Dario Markenartikelvertrieb $\mathrm{GmbH}$ and Co KG, Hamburg, Germany) and compared to earlier work [18]. The element maps of an entire leaf were collected without sample damage after 4-20 h of measurement with a maximum dwell time of $600 \mathrm{~ms}$ in each spot. For full quantification the $N$. caerulescens pixels were binned to the lowest amount the software could process $(5 \times 5$ to $9 \times 9)$. The reduced resolution did not affect the conclusions since the epidermal cells in $N$. caerulescens have sizes in the range of $100 \mu \mathrm{m}[18,41]$. The $\mu$ XRF maps of crop plants (C. annum and G. max) were not fully quantified, but shown as semi-quantitative maps after spectral deconvolution, in order to avoid the pixel binning and corresponding loss of resolution. Their measured areas were smaller $(5 \times 5 \mathrm{~mm}$ for leaves, and up to $3 \times 2 \mathrm{~mm}$ for roots) so that the number of pixels was not a problem, but Gaussian smoothing was needed 
to reduce noise. Gaussian smoothing and assignment of colour scales were done in the Fiji version of ImageJ [42]. Maps were assembled, arranged and labelled using PhotoImpact X3 (Corel Corporation, Ottawa, Canada).

Samples were measured in triplicates for the five developmental stages of $N$. caerulescens leaves. Positions 2 and 3 were later averaged due to their similarity. Mean values and standard deviations were calculated in Numbers (macOS High Sierra 10.13.6, Apple, Cupertino, CA, USA). Four leaves from four independently grown plants were measured from C. annuum. The root of G. max was measured $2 \times$, once the emerging root hair and once the tip of the lateral root.

\section{Statistical analysis}

Statistics was analysed in Origin Professional (versions 2015 and 2019; Originlab Corporation, Northampton, MA, USA). For analysis of chlorophyll fluorescence parameters that are saturating and do not have normal distribution $\left(\Phi_{\mathrm{Po}}, \Phi_{\mathrm{RE} 1 \mathrm{o}}, \Phi_{\mathrm{Et} 2 \mathrm{o}}\right.$ and $\left.\Phi_{\mathrm{PSII}}\right)$, the non-parametric Mann-Whitney U test [43] was used for comparison of the X-ray exposed and the adjacent leaf area (same size, bordering the exposed area). One-way repeated measures ANOVA and pair-wise comparison (Bonferroni test) were used to distinguish the effects of X-ray on the same leaf measuring area by comparing the values of NPQ_i1 before and after the X-ray exposure. This test deals with dependent variable which is subjected to repeated measurements-the independence assumption is not considered. The significance level of 0.05 was applied.

\section{Results}

\section{Characterization of the system and measuring conditions} Object with a topography and focusing

Leaf samples show a topography with a structure of main veins, smaller veins, and in the case of $N$. caerulescens and $A$. halleri a rippled leaf border. This poses a challenge for focusing. Samples were focused in the middle of the leaf but away from the main vein. To avoid defocusing, the leaves were supported with a 3D-printed Nylon plate with a grid of holes to allow for humidity and air permeation. In a test, the leaf was moved out of focus down, which reduced the detected metal concentration from $2390 \mathrm{mg} \mathrm{kg}^{-1}$ in focus to $2262 \mathrm{mg} \mathrm{kg}^{-1}$ at $250 \mu \mathrm{m}$ out of focus and $2225 \mathrm{mg} \mathrm{kg}^{-1}$ at $360 \mu \mathrm{m}$ out of focus. Thus, the change of total metal content in the full image was minimal (at most $7 \%$ at $360 \mu \mathrm{m}$ ) since defocusing means that a bigger or smaller solid angle is targeted by the beam.

When looking into smaller features like trichomes in Arabidopsis halleri, the effects of defocusing became more pronounced (Fig. 4). The loss of focus was much worse for the optical image taken by the camera



Fig. 4 Effect of focusing on the element map of trichomes. A $1 \times 1 \mathrm{~mm}$ area of an $A$. halleri leaf was measured in a single cycle with $150 \mathrm{~ms}$ integration time per point and $4 \mu \mathrm{m}$ point distance. Measured with He atmosphere in the hutch but air in the measuring chamber. The element maps of this figure are semi-quantitative, obtained by spectral deconvolution but without normalization to a standard. Therefore, the units are detector counts, instead of concentration units

compared to the loss of focus of features on the element distribution maps, which is due to the different optics. Because of the X-ray excitation coming in an angle (Fig. 3), the defocusing led to a displacement of the $\mu$ XRF map relative to the optical image. In an object with a topography, the latter effect always leads to some distortion of the $\mu$ XRF map (Fig. 4). Nevertheless, strong accumulation of $\mathrm{Zn}$ was observed in the trichome base, and $\mathrm{Ca}$ was observed in the trichome body, while less $\mathrm{Ca}$ accumulation was observed in the base and in the trichome tips. This matches earlier work on A. halleri leaves by scanning electron microscopy with Energy Dispersive X-Ray Analysis (EDX) element analysis and mapping EDX [44]. Accumulation of calcium phosphate in trichomes of several plant species including Arabidopsis thaliana was later analysed in the same way [45]. Similar to our findings, in all cases the lowest $\mathrm{Ca}$ accumulation was in the trichome base, allowing elasticity, and the role of trichomes as mechanical sensors was discussed. 
Measuring leaves in vivo: ensuring the fitness of the specimen No visible signs of damage by the X-rays could be observed on the pepper leaves after about $20 \mathrm{~h}$ long measurements (Fig. 5). Fast and slow chlorophyll fluorescence kinetics were measured before and after $\mu \mathrm{XRF}$ measurements and the parameters were calculated for the whole leaves, and on directly X-ray exposed and adjacent area. Overall, on the whole leaf level, no significant differences in photosynthetic parameters could be observed in relation to X-ray exposure (not shown). On the other hand, when the parameters (presented as a ratio before and after the X-ray measurement to exclude differences between the leaves) were compared between the measured area and an adjacent area, a significant decrease in $\Phi_{\mathrm{ET} 2 \mathrm{o}}$ was observed in the X-ray exposed area, while the effects on $\Phi_{\text {Po }}$ and $\Phi_{\text {RE1o }}$ were not so pronounced (Fig. 5, Table 1). Maximal yield of photochemistry $\left(\Phi_{\mathrm{Po}}=1-\mathrm{F}_{0} / \mathrm{F}_{\mathrm{p}}\right)$ was not the most sensitive parameter, as both $\mathrm{F}_{0}$ and $\mathrm{F}_{\mathrm{p}}$ (equals $\mathrm{F}_{\mathrm{m}}$ ) slightly decreased as a result of the $\mu \mathrm{XRF}$ measurement.

Slow chlorophyll fluorescence kinetics revealed no changes in $F_{v} / F_{m}$ in relation to X-ray exposure neither in the whole leaf nor in the X-ray exposed area (not shown). However, the non-photochemical quenching determined here as $N P Q=\left(F_{m}-F_{m}^{\prime}\right) / F_{m}^{\prime}$ during the irradiance phase (NPQ_i1 to NPQ_i3) was increased in the measured leaf area after the X-ray exposure (Fig. 5, significant effect of $\mathrm{X}$-ray exposure determined by one-way repeated ANOVA, Table 2) from $0.089 \pm 0.031$ to $0.290 \pm 0.041$ before and after the measurement, respectively. These results indicate the activation of photoprotective mechanisms such as heat dissipation due to decreased electron transport efficiency under X-rays. Operating efficiency of PSII $\left(\Phi_{\mathrm{PSII}}=\left(\mathrm{F}_{\mathrm{m}}^{\prime}-\mathrm{F}_{0}^{\prime}\right.\right.$ )$/ \mathrm{F}_{\mathrm{m}}^{\prime}$ ) was also slightly lower after the X-ray exposure, although not significantly different compared to the adjacent area.

\section{Compton scattering images}

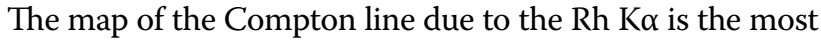
intense and gives information of the inelastic scattering occurring at the supports and in the sample. It is most sensitive to the low $\mathrm{Z}$ elements. In the sample mounting used for plants, with water below the leaf for in vivo measurements, the scattering builds up strongly at the materials used as support and hinders the use of the Compton images of the leaves. For low concentration elements, a strong scattering might contaminate the fluorescence map.
For those low concentration elements, the comparison of the fluorescence image with the Compton image helps to determine the real nature of the features observed in the fluorescence image (Fig. 6).

\section{Quantification with M4 and Xmethod on a certified liquid standard}

A test of the quantification was done on a certified liquid standard for ICP-MS (standard solution VI, Merck KGaA Darmstadt Germany) using as calibration three dilutions of the liquid reference material of the synchrotron tomography [46]. Therefore, the certified liquid standard allowed a "quality test" of the quantification with the benchtop X-ray machine. The results are displayed in Tables 3 and 4 .

\section{Quantification with M4 and Xmethod using foil standards}

The foil standards reproduce at best the leaf matrix and its thickness. Therefore, all final quantifications of leaf measurements were done with the foil standards. Their concentrations measured by ICP-sfMS are shown in Table 5 . The calibration parameters of the $\mu$ XRF measurement are shown in Tables 6 and 7.

\section{Limits of detection}

The limits of detection (LOD) for both the liquid and foil standards were calculated with the formula [47]:

$$
L O D=\frac{3 * c * \sqrt{2 * N_{b k g}}}{N_{\text {net }}}
$$

with c: concentration, $\mathrm{N}_{\mathrm{bkg}}$ : background counts, and $\mathrm{N}_{\text {net }}$ : peak counts. The results are shown in Table 8.

\section{Application examples Flat object 1: metal distribution and leaf development stage in $N$. caerulescens}

Figure 7 shows the fluorescence images for $\mathrm{Zn}$ distribution for five different development stages of the $N$. caerulescens leaves, from the rosette apical meristem-young leaf (position 0) to a mature, but not senescent, leaf at the base of the plant (position 4). The high-resolution image shows a structure of $\mathrm{Zn}$ distribution that resembles the tissue structure and $\mathrm{Ni}$ distribution seen for the related $N$. goesingense (= Thlaspi goesingense) in Küpper et al. [48], as well $\mathrm{Zn}$ distribution in $N$. caerulescens [18].

\footnotetext{
(See figure on next page.)

Fig. 5 Maps of chlorophyll fluorescence kinetics parameters before and after the $\mu$ XRF experiment in vivo. A $5 \times 5 \mathrm{~mm}$ area of a pepper (C. annuum, cultivar 'Kozy Roh') leaf was measured in a single cycle with 600 ms integration time per point and $15 \mu \mathrm{m}$ point distance. This resulted in an approx. $20 \mathrm{~h}$ total measuring time. The $\mu$ XRF measurements for these leaves are shown in Fig. 8. $\Phi_{\text {po }}-$ maximum quantum yield of primary PSII photochemistry, $\Phi_{E T 20}$ - quantum yield of the electron transport flux from $\mathrm{Q}_{\mathrm{A}}$ to $\mathrm{Q}_{\mathrm{B}}$, and $\Phi_{\mathrm{RE} 10}$ - quantum yield of the electron transport flux until $\mathrm{PSI}$ electron acceptors, $N P Q_{-i 1}$ complete non-photochemical quenching $\left(\mathrm{NPQ}=\left(\mathrm{F}_{\mathrm{m}}-\mathrm{F}_{\mathrm{m}}^{\prime}\right) / \mathrm{F}_{\mathrm{m}}^{\prime}\right)$ at the onset of irradiance
} 


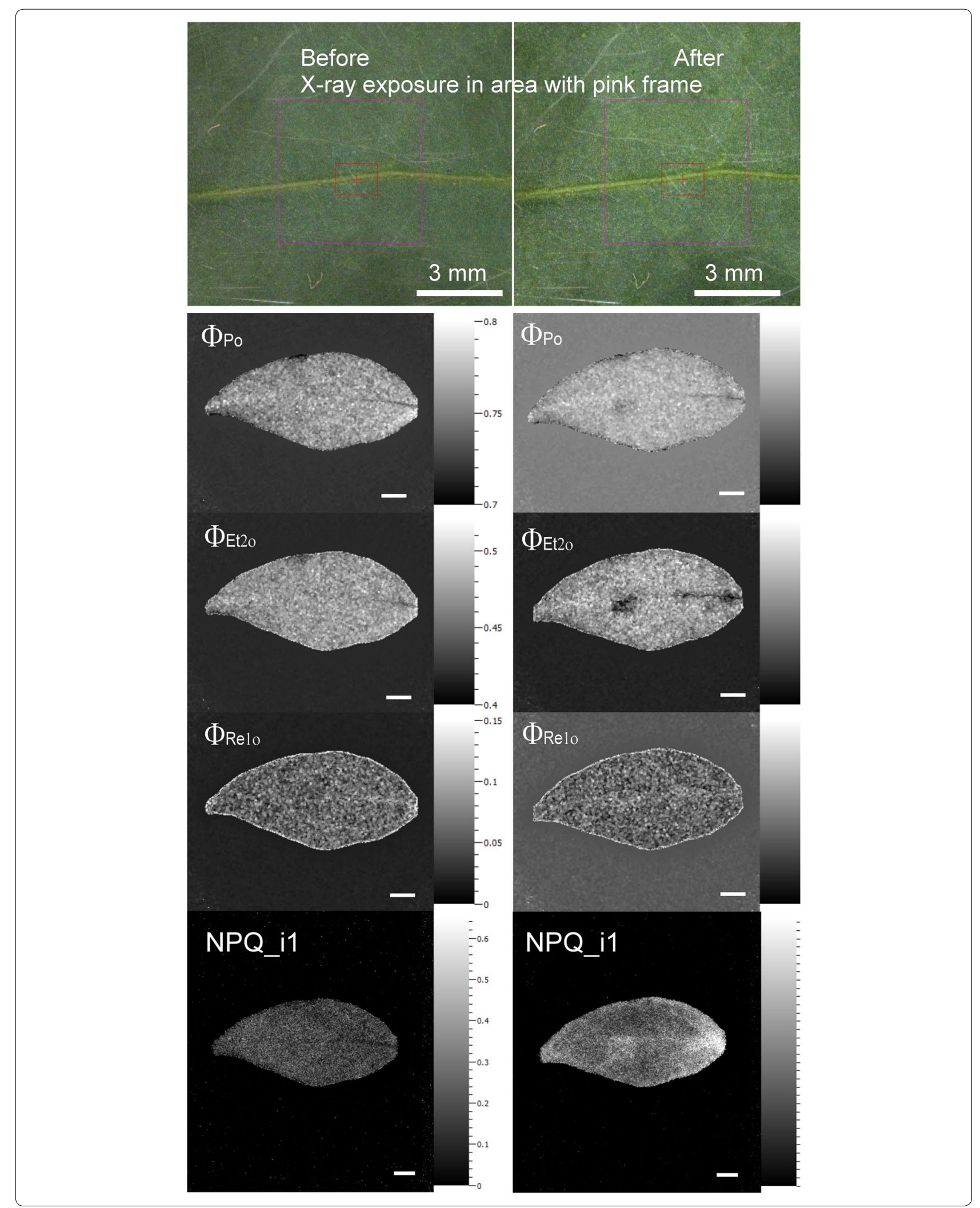


Table 1 Mann-Whitney $U$ test statistics for significant differences at the $\mathbf{0 . 0 5}$ probability level (marked with asterisks sign) in OJIP parameters between X-ray exposed and non-exposed adjacent area (the same size and bordering the exposed area) of pepper leaves $(n=4)$

\begin{tabular}{|c|c|c|c|c|c|}
\hline Chl fluorescence parameters & $\mathbf{N}$ & Median & $\mathbf{U}$ & Z & Asymp. Prob $>|\mathrm{U}|$ \\
\hline \multicolumn{6}{|l|}{$\Phi_{\text {Po }}$} \\
\hline Area under X-ray & 4 & 0.985 & 3 & -1.29904 & 0.19393 \\
\hline Adjacent area & 4 & 0.993 & & & \\
\hline \multicolumn{6}{|l|}{$\Phi_{\text {RE10 }}$} \\
\hline Area under X-ray & 4 & 1.23 & 12 & 1.01036 & 0.31232 \\
\hline Adjacent area & 4 & 1.1 & & & \\
\hline \multicolumn{6}{|l|}{$\Phi_{\mathrm{ET} 20}$} \\
\hline Area under X-ray & 4 & 0.951 & 0 & -2.16506 & $0.03038^{*}$ \\
\hline Adjacent area & 4 & 0.991 & & & \\
\hline \multicolumn{6}{|l|}{$\Phi_{\mathrm{PS} \|}$} \\
\hline Area under X-ray & 4 & 0.823 & 4 & -1.01036 & 0.31232 \\
\hline Adjacent area & 4 & 0.883 & & & \\
\hline
\end{tabular}

The $\mathrm{Z}$ value represents standardized value corrected for the presence of ties in case of similar values which are assigned to the same rank. Asymp. Prob $>|\mathrm{U}|$ indicates the asymptotic significance; when it is lower than the statistical threshold, the alternative hypothesis that the two distributions are different, is accepted. $\Phi_{\mathrm{Po}_{\mathrm{O}}}-$ maximum quantum yield of primary PSIl photochemistry, $\Phi_{E T 20}$ - quantum yield of the electron transport flux from $Q_{A}$ to $Q_{B}$, and $\Phi_{R E 10}-q u a n t u m$ yield of the electron transport flux until PSI electron acceptors according to Stirbet and Govindjee [33]. $\Phi_{\text {PSII- }}$ operating PSII efficiency according to Küpper et al. [25]

Table 2 (A) Results of one-way repeated measures ANOVA and (B) pair-wise comparison for differences in NPQ of the same area before and after X-ray exposure $(n=4)$

\begin{tabular}{|c|c|c|c|c|c|c|c|}
\hline \multicolumn{8}{|c|}{ (A) Repeated ANOVA, test of within subjects effect } \\
\hline & & Sum of squares & DF & Mean square & $\mathbf{F}$ & Prob $>F$ & \\
\hline X-ray treatment & Sphericity assumed & 0.0804 & 1 & 0.0804 & 11.32322 & $0.04357^{*}$ & \\
\hline Error (xray) & Sphericity assumed & 0.0213 & 3 & 0.0071 & & & \\
\hline \multicolumn{8}{|c|}{ (B) Pairwise comparison, Bonferroni test } \\
\hline & Index & Mean difference & Std. error & DF & Prob $>|t|$ & $95 \% \mathrm{LCL}$ & $95 \%$ UCL \\
\hline Before/after $X$-ray treatment & 0 & -0.2005 & 0.05958 & 3 & $0.04357^{*}$ & -0.39012 & -0.01088 \\
\hline
\end{tabular}

$N P Q_{-i 1}$ - complete non-photochemical quenching $\left(\left(F_{m}-F_{m}^{\prime}\right) / F_{m}\right)$ at the onset of irradiance phase ( $\left.\_i 1\right)$ according to Küpper et al. [25]. Significant differences are emphasized with asterisks

In both species the epidermal cells have a wide range of sizes, with large cells ("metal storage cells") accumulating the highest $\mathrm{Zn}$ and Ni content far away from stomata, and the smaller cells around the stomatal guard cells.

Young, actively growing leaves of $N$. caerulescens already accumulated high amounts of $\mathrm{Zn}$. Leaves taken at the rosette apical meristem accumulated about $3000 \mathrm{mg} \mathrm{kg} \mathrm{Zn}^{-1} \mathrm{Z}$. The $\mathrm{Zn}$ concentration increased in a non-linear manner with leaf age, reaching about $7500 \mathrm{mg} \mathrm{kg}^{-1}$ in the oldest mature leaves. Leaf size and metal content variability were important at all stages of the plant development. Quantification of $\mathrm{Zn}$ fluorescence was compared with ICP-MS analysis for individual leaves (Table 9). On average, the mean values for $\mathrm{Zn}$ content between XRF and ICP-MS measurements differed up to $20 \%$, except for older leaves where the difference was slightly higher. Regarding Zn distribution, in young leaves the highest accumulation was observed towards the tip and in the veins. The oldest leaf had a more homogeneous $\mathrm{Zn}$ distribution, and the highest concentration in the veins and rims. As both, the exciting X-ray beam and the $\mathrm{Zn} \mathrm{K} \alpha$ fluorescence, penetrates through the leaf, in such 2D-scans of intact leaves it is not possible to distinguish from which depth inside the leaf the signal originates. It could be epidermis or mesophyll for regions between veins, and epidermis above veins or epidermis itself when looking at a vein. Earlier work using SEM-EDX on frozen-hydrated leaf sections showed that $\mathrm{Zn}$ is mostly in the epidermis [18], but in that work the macroscopic distribution (tip vs. base, veins vs. interveinal areas) could not be analysed. A study of metal distribution of $N$. caerulescens using laser ablation-inductively coupled plasma mass spectrometry (LA-ICP-MS) showed gradual increase in $\mathrm{Zn}$ accumulation from the base to the leaf tip, 

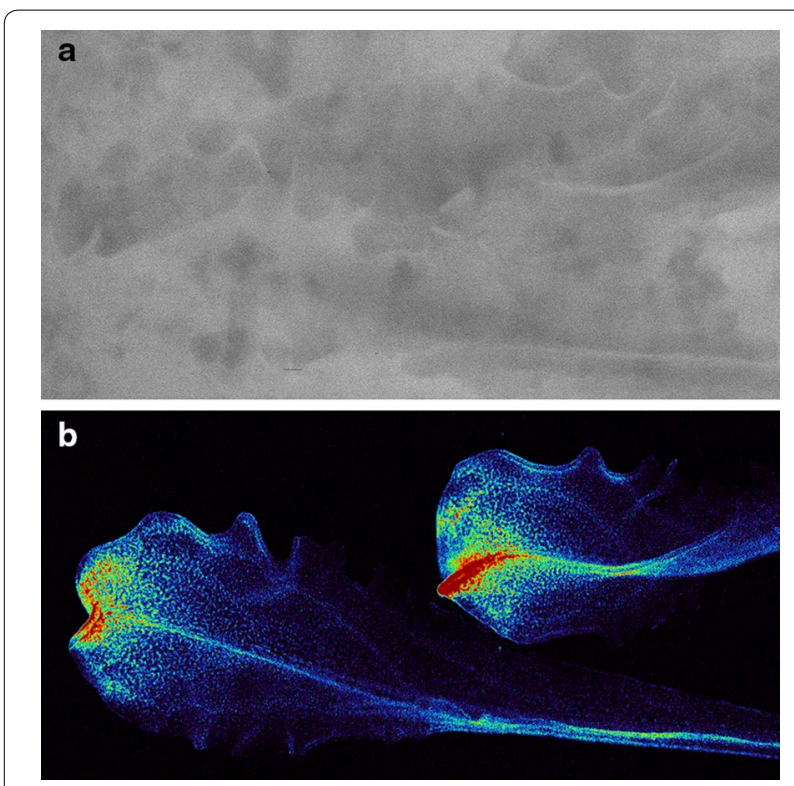

Fig. 6 Map of the Compton peak at about $18.9 \mathrm{keV}(\mathbf{a})$ corresponding to the Rh Ka line of Rh and Zn fluorescence map (b). Both images correspond to the two rosette leaves (position 0 ) of N. caerulescens. Point distance is $15 \mu \mathrm{m}$ and integration time is $10 \mathrm{~ms}$ the mesophyll and localized mostly in stomatal guard cells of the epidermis (see zoomed image), with no enrichment in the veins, $\mathrm{Zn}$ was predominately accumulated in the veins. In the larger veins most of the $\mathrm{Zn}$ accumulated in the bundle sheath cells (see labels in Fig. 8). Only very low $\mathrm{Zn}$ concentrations were found in the mesophyll. Manganese distribution was opposite to that of $\mathrm{Zn}$ : no accumulation in the midrib, but higher accumulation in the smaller veins and the mesophyll, with a distinct pattern that might reflect the structure of the spongy mesophyll. Fe and $\mathrm{K}$ were in between these two extremes, with somewhat higher accumulation in the veins than in the mesophyll.

\section{Cylindrical object: soybean roots}

In fresh, living state, roots turned out to be the most challenging plant organs for analysis with $\mu \mathrm{XRF}$, not only for the benchtop system presented here (Fig. 9) but also in recent synchrotron beamtimes of the team (not shown). There are two main reasons why roots of non-accumulator plants at non-toxic trace metal concentrations are difficult samples for this technique. First, the water content is much higher than that of leaves or seeds. Thus, their

Table 3 Concentrations of $\mathrm{Mn}, \mathrm{Fe}, \mathrm{Ni}, \mathrm{Cu}$ and $\mathrm{Zn}$ for the certified liquid standard

\begin{tabular}{|c|c|c|c|c|c|}
\hline Sample & $\mathrm{Mn}\left[\mathrm{mg} \mathrm{kg}^{-1}\right]$ & $\mathrm{Fe}\left[\mathrm{mg} \mathrm{kg}^{-1}\right]$ & $\mathrm{Ni}\left[\mathrm{mg} \mathrm{kg}^{-1}\right]$ & $\mathrm{Cu}\left[\mathrm{mg} \mathrm{kg}^{-1}\right]$ & $\mathrm{Zn}\left[\mathrm{mg} \mathrm{kg}^{-1}\right]$ \\
\hline$\mu X R F$ result & 6.85 & 90.60 & 8.48 & 8.47 & 87.90 \\
\hline $\begin{array}{l}\text { Certificate of analysis (manu- } \\
\text { facturer) }\end{array}$ & $9.9 \pm 0.5$ & $100 \pm 5$ & $9.9 \pm 0.5$ & $9.9 \pm 0.5$ & $99 \pm 5$ \\
\hline RSE \% & 18.21 & 4.93 & 7.73 & 7.78 & 5.94 \\
\hline
\end{tabular}

Data from: (a) $\mu$ XRF quantification, (b) datasheet of manufacturer (Merck). Data were collected for an area and the average of the pixel grey values was used. The relative standard error percentage (SE/mean $\%$, with $n=2$ and SE $=$ STDEV/sqrt(n)) shows the difference between the $\mu$ XRF result and the certificate of analysis

but for the oldest leaf [49]. Comparison with the current work is difficult since the growing conditions were different (1/5 of Hoagland's solution, and fivefold more $\mathrm{Zn}$ than in this work) and the leaf was scanned by ablation for $15 \mathrm{~h}$ without cryoprotection.

\section{Flat object 2: element distribution in the leaves of pepper}

High sensitivity for trace elements was achieved after comprehensive system optimization as described in the Methods section. As a result, micronutrients could be analysed in natural abundance in crop plants, as shown by the analysis of a pepper leaf (Fig. 8). The multielement analysis by ICP-MS of leaves from the same plants is shown in Additional file 6: Table S1. The signals of Fe, $\mathrm{Mn}$ and $\mathrm{Zn}$ were high enough to yield high-resolution maps, so that their distribution could be compared to that of the more abundant macronutrients, $\mathrm{Ca}$ and $\mathrm{K}$ (Fig. 8). While Ca was homogeneously distributed in ratio of fresh mass to dry mass is very high (about 20 for soybean roots), and the high metal concentrations usually reported on a dry mass basis translate to very small concentrations in fresh living tissue. The concentrations measured by ICP-MS on dried homogenised roots of soybean are shown in Additional file 6: Table S1. This could be overcome by the sensitivity optimization of the current system, as shown in Fig. 9. In the lateral root tip, all known micronutrients $(\mathrm{Cu}, \mathrm{Fe}, \mathrm{Mn}, \mathrm{Ni}, \mathrm{Zn})$ could be visualized with reasonable signal/noise ratio (Fig. 9a). The concentration of $\mathrm{Cu}$ in the emerging root hair became too low to be visualized, but the other micronutrients remained well measurable (Fig. 9b). In the root tip the signal intensity for all elements was the lowest in the root cap; $\mathrm{Zn}$ was mostly accumulated in the meristem and in the endodermis of the main root, while Fe accumulation was more pronounced in the elongation zone. Secondly, 
Table 4 Calibration for the liquid standards: content in standard sample measured with ICP-MS and the calculated value from the $\mu$ XRF calibration

\begin{tabular}{|c|c|c|c|c|c|c|c|}
\hline Standard samples & $\mathrm{K}\left[\mathrm{mg} \mathrm{kg}^{-1}\right]$ & $\mathrm{Ca}\left[\mathrm{mg} \mathrm{kg}^{-1}\right]$ & $\mathrm{Mn}\left[\mathrm{mg} \mathrm{kg}^{-1}\right]$ & $\mathrm{Fe}\left[\mathrm{mg} \mathrm{kg}^{-1}\right]$ & $\mathrm{Ni}\left[\mathrm{mg} \mathrm{kg}^{-1}\right]$ & $\mathrm{Cu}\left[\mathrm{mg} \mathrm{kg}^{-1}\right]$ & $\mathrm{Zn}\left[\mathrm{mg} \mathrm{kg}^{-1}\right]$ \\
\hline \multicolumn{8}{|l|}{ Std 1} \\
\hline ICP-MS & 195 & 200 & 275 & 279 & 293 & 318 & 327 \\
\hline$\mu \mathrm{XRF}$ & 194 & 203 & 274 & 272 & 294 & 315 & 327 \\
\hline \multicolumn{8}{|l|}{ Std 2} \\
\hline ICP-MS & 98 & 100 & 137 & 140 & 147 & 159 & 164 \\
\hline$\mu \mathrm{XRF}$ & 101 & 86 & 140 & 154 & 146 & 166 & 162 \\
\hline \multicolumn{8}{|l|}{ Std 3} \\
\hline ICP-MS & 49 & 50 & 69 & 70 & 73 & 79 & 82 \\
\hline$\mu \mathrm{XRF}$ & 47 & 61 & 67 & 62 & 74 & 75 & 82 \\
\hline \multicolumn{8}{|l|}{ Std 1} \\
\hline RSE \% & 0.26 & 0.74 & 0.18 & 1.27 & 0.17 & 0.47 & 0.26 \\
\hline \multicolumn{8}{|l|}{ Std 2} \\
\hline RSE \% & 1.51 & 7.53 & 1.08 & 4.76 & 0.34 & 2.15 & 1.51 \\
\hline \multicolumn{8}{|l|}{ Std 3} \\
\hline RSE \% & 2.08 & 9.91 & 1.47 & 6.06 & 0.68 & 2.60 & 0.00 \\
\hline
\end{tabular}

The relative standard error percentage (SE/mean $\%$, with $n=2$ and SE $=$ STDEV/sqrt(n)) shows the difference between the $\mu$ XRF result and the ICP-MS

Table 5 Quantification of the foil standards with ICP-MS: PVA 1-XX indicates the dilution in XX parts

\begin{tabular}{|c|c|c|c|c|c|}
\hline & $\mathrm{Mn}\left[\mathrm{mg} \mathrm{kg}^{-1}\right]$ & $\mathrm{Fe}\left[\mathrm{mg} \mathrm{kg}^{-1}\right]$ & $\mathrm{Ni}\left[\mathrm{mg} \mathrm{kg}^{-1}\right]$ & $\mathrm{Cu}\left[\mathrm{mg} \mathrm{kg}^{-1}\right]$ & $\mathrm{Zn}\left[\mathrm{mg} \mathrm{kg}^{-1}\right]$ \\
\hline Reagent Blank1 & 0 & 0 & 0 & 0 & 0 \\
\hline Reagent Blank2 & 0 & 0 & 0 & 0 & 0 \\
\hline PVA zero & 1 & 2 & 0 & 1 & 1 \\
\hline PVA 1-100 & 3 & 4 & 16 & 4 & 529 \\
\hline PVA 1-50 & 3 & 5 & 19 & 5 & 634 \\
\hline PVA 1-30 & 5 & 9 & 34 & 8 & 1108 \\
\hline PVA 1-20 & 8 & 13 & 56 & 13 & 1835 \\
\hline PVA 1-10 & 15 & 22 & 104 & 24 & 3352 \\
\hline PVA 1-5 & 39 & 56 & 264 & 59 & 8719 \\
\hline PVA 1-3 & 63 & 91 & 434 & 94 & 14,482 \\
\hline PVA 1-2 & 92 & 131 & 630 & 137 & 27,528 \\
\hline PVA 1-1 & 167 & 241 & 1158 & 244 & 52,207 \\
\hline
\end{tabular}

Table 6 Concentrations in the foil 1-1, thickness $450 \mu \mathrm{m}$, determined by: (a) $\mu$ XRF, (b) ICP-MS

\begin{tabular}{|c|c|c|c|c|c|c|c|}
\hline $\begin{array}{l}\text { Foil } \\
1-1\end{array}$ & $\mathrm{~K}\left[\mathrm{mg} \mathrm{kg}^{-1}\right]$ & $\mathrm{Ca}\left[\mathrm{mg} \mathrm{kg}^{-1}\right]$ & $\mathrm{Mn}\left[\mathrm{mg} \mathrm{kg}^{-1}\right]$ & $\mathrm{Fe}\left[\mathrm{mg} \mathrm{kg}^{-1}\right]$ & $\mathrm{Ni}\left[\mathrm{mg} \mathrm{kg}^{-1}\right]$ & $\mathrm{Cu}\left[\mathrm{mg} \mathrm{kg}^{-1}\right]$ & $\mathrm{Zn}\left[\mathrm{mg} \mathrm{kg}^{-1}\right]$ \\
\hline$\mu X R F$ & 1119 & 1444 & 182 & 265 & 1161 & 276 & 52,763 \\
\hline ICP-MS & 1091 & 1378 & 167 & 241 & 1158 & 244 & 52,207 \\
\hline RSE \% & 1.27 & 2.34 & 4.30 & 4.74 & 0.13 & 6.15 & 0.53 \\
\hline
\end{tabular}

The relative standard error percentage (SE/mean $\%$, with $n=2$ and SE $=$ STDEV/sqrt(n)) shows the difference between the $\mu$ XRF result and the ICP-MS

roots are cylindrical, which causes problems for quantification in a benchtop $\mu$ XRF system, because only projections from 2D scanning are possible, while tomography is not feasible with the current equipment.

\section{Discussion}

This work showed that the customized version of M4 TORNADO is suited for measuring samples in vivo, contrary to standard benchtop $\mu \mathrm{XRF}$ machines. This was 
Table 7 Calibration for the foil standards: content in standard sample measured with ICP-MS and its calibrated value from $\mu$ XRF

\begin{tabular}{|c|c|c|c|c|c|c|c|}
\hline Standard samples & $\mathrm{K}\left[\mathrm{mg} \mathrm{kg}^{-1}\right]$ & $\mathrm{Ca}\left[\mathrm{mg} \mathrm{kg}^{-1}\right]$ & $\mathrm{Mn}\left[\mathrm{mg} \mathrm{kg}^{-1}\right]$ & $\mathrm{Fe}\left[\mathrm{mg} \mathrm{kg}^{-1}\right]$ & $\mathrm{Ni}\left[\mathrm{mg} \mathrm{kg}^{-1}\right]$ & $\mathrm{Cu}\left[\mathrm{mg} \mathrm{kg}^{-1}\right]$ & $\mathrm{Zn}\left[\mathrm{mg} \mathrm{kg}^{-1}\right]$ \\
\hline \multicolumn{8}{|l|}{ Std 1} \\
\hline ICP-MS & 1091 & 1378 & 167 & 241 & 1158 & 244 & 52,207 \\
\hline$\mu X R F$ & 1119 & 1444 & 181 & 262 & 1158 & 277 & 52,978 \\
\hline \multicolumn{8}{|l|}{ Std 2} \\
\hline ICP-MS & 615 & 772 & 92 & 131 & 630 & 137 & 27,528 \\
\hline$\mu X R F$ & 513 & 628 & 89 & 120 & 647 & 125 & 25,418 \\
\hline \multicolumn{8}{|l|}{ Std 3} \\
\hline ICP-MS & 430 & 544 & 63 & 91 & 434 & 94 & 14,482 \\
\hline$\mu X R F$ & 441 & 530 & 52 & 78 & 402 & 73 & 15,120 \\
\hline \multicolumn{8}{|l|}{ Std 4} \\
\hline ICP-MS & 51 & 68 & 5 & 9 & 34 & 8 & 1108 \\
\hline$\mu X R F$ & 72 & 129 & 0 & 12 & 49 & 0 & 1858 \\
\hline \multicolumn{8}{|l|}{ Std 5} \\
\hline ICP-MS & 36 & 74 & 3 & 4 & 16 & 4 & 529 \\
\hline$\mu X R F$ & 78 & 105 & 0 & 0 & 16 & 0 & 480 \\
\hline \multicolumn{8}{|l|}{ Std 1} \\
\hline RSE \% & 1.27 & 2.34 & 4.02 & 4.17 & 0.00 & 6.33 & 0.73 \\
\hline \multicolumn{8}{|l|}{$\operatorname{Std} 2$} \\
\hline RSE \% & 9.04 & 10.29 & 1.66 & 4.38 & 1.33 & 4.58 & 3.99 \\
\hline \multicolumn{8}{|l|}{ Std 3} \\
\hline RSE \% & 1.26 & 1.30 & 9.57 & 7.69 & 3.83 & 12.57 & 2.16 \\
\hline \multicolumn{8}{|l|}{ Std 4} \\
\hline RSE \% & 17.07 & 30.96 & 100.00 & 14.29 & 18.07 & 100.00 & 25.29 \\
\hline \multicolumn{8}{|l|}{ Std 5} \\
\hline RSE \% & 36.84 & 17.32 & 100.00 & 100.00 & 0.00 & 100.00 & 4.86 \\
\hline
\end{tabular}

The relative standard error percentage (SE/mean $\%$, with $n=2$ and SE $=$ STDEV/sqrt(n)) shows the difference between the $\mu$ XRF result and the ICP-MS

Table 8 Limits of detection (LOD) for the liquid reference from Merk and for the reference foil (foil with $450 \mu \mathrm{m}$ thickness)

\begin{tabular}{llllllrr}
\hline & K & Ca & Mn & Fe & Ni & Cu & Zn \\
\hline Standard from Merck & - & - & 17 & 15 & 8 & 13 \\
Foil with 450 $\mu$ m thickness & 494 & 269 & 24 & 16 & 19 & 104 \\
\hline
\end{tabular}

made possible by four key factors:

1. The choice of the maximal effective detector area commercially offered, i.e. $2 \times 60 \mathrm{~mm}^{2}$ active area. This maximizes the solid angle and thus the efficiency of fluorescence detection, minimizing the $\mathrm{X}$-ray irradiation that is needed for obtaining a good signal to noise ratio. Primary emission filters may be employed to absorb unwanted regions of the polychromatic exciting X-ray spectrum. The large area of the detectors facilitates the collection of spurious counts from scattering in other parts of the machine.
This unwanted effect was minimized by the additional shielding in the detector.

2. The construction and implementation of a chamber for measuring plant samples under physiological conditions such as flow of water-saturated air or liquid media. The sample chamber is tightly enclosed to avoid moisture on beryllium detector windows or in the electronics. Thus, since the sample is enclosed, the hutch of the $\mu$ XRF may even be kept in $\mathrm{He}$ atmosphere. It is also possible to measure in air, that is, in the living conditions for the plant. The energy transfer to the sample by the photon flux is lower than in the case of electrons, minimizing the heating. 


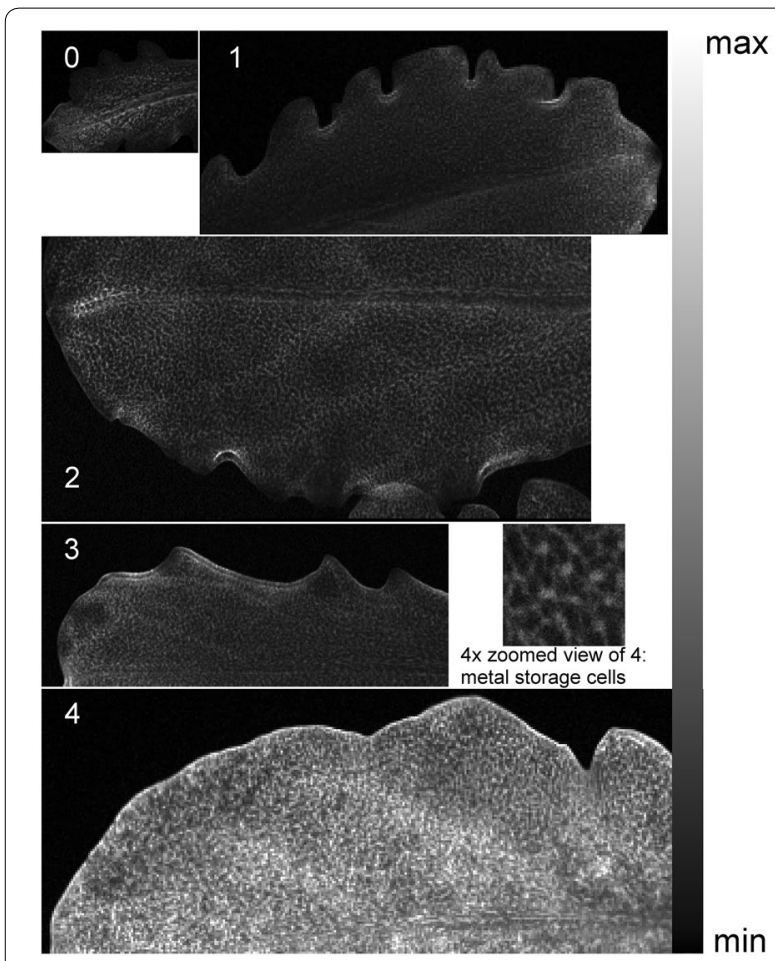

Fig. 7 Quantified fluorescence maps of the Zn K-edge of $N$. caerulescens for leaves at different stages of development from rosette (0) to the mature leaves at the base of the plant (4). The grey scale on the right side represents the concentrations from 0 (black) to maximum (white). White corresponds to: $12,605 \mathrm{mg} \mathrm{kg}^{-1}$ for the leaf at position 4 (base), $3389 \mathrm{mg} \mathrm{kg}^{-1}$ for position 3, $3041 \mathrm{mg} \mathrm{kg}^{-1}$ for pos 2, $2602 \mathrm{mg} \mathrm{kg}^{-1}$ for pos 1, and $2724 \mathrm{mg} \mathrm{kg}^{-1}$ for the leaf at position 0 (rosette). These values are corrected to match the difference in mass between the fresh leaves in $\mu$ XRF with dry mass in ICPMS. Point distance is $15 \mu \mathrm{m}$ and integration times are: $25 \mathrm{~ms}$ for 0 , $3 \mathrm{~ms}$ for (1)-(4). Pixels are averaged $(5 \times 5$ to $9 \times 9)$ in the quantified images due to limitations of the software to deal with high pixel number. The full resolution zoom shows the epidermal metal storage cells [18]

The special mounting in a special measuring cell with liquid and air flow also serves to cool the sample. The compatibility of this chamber with microscopic and macroscopic imaging of UV/VIS fluorescence allows for direct correlation of element distribution with measurements of physiological parameters on the same sample. In the current study, this was used to assess the effect of the X-ray exposure on photosynthesis via fast imaging measurements of Chl fluorescence induction. In principle, measuring detached leaves (or roots) is certainly not as ideal "in vivo" as measuring on an intact plant. But for most plant species the measurement of an intact entire plant in any $\mathrm{XRF}$ or UV/VIS/NIR fluorescence imaging device is not possible simply due to size restrictions, so that keeping a detached organ as vital as possible as in the current work is the closest possible match to the ideal "in vivo" condition.

3. Optimization of the machine and the measuring chamber used for analysis of leaves of a non-accumulator plant, pepper, for about $20 \mathrm{~h}$ in the $\mu \mathrm{XRF}$ machine ensured that the leaf remained intact without severe damage of photosynthetic apparatus. This was confirmed by comparing photosynthetic parameters before and after the X-ray exposure. In addition, we observed higher sensitivity of PSII to radiation than PSI. To our knowledge, the studies of the effects of X-rays on plant performance are scarce, but could become important for the growth of plants on space stations. In experiments aimed at revealing X-ray $\mathrm{CT}$ of living rose plants, performed in a synchrotron [50], significant structural damage was observed. In a later similar study on more species, strong RNA and membrane damage was found [51]. Dose-dependent $\mathrm{X}$-ray inhibition of photosynthetic oxygen evolution was observed in Chlorella pyrenoidosa [52]. In bean plants, in an experiment aimed at determining stress to plants in Bioregenerative Life Support Systems (BLSS) of space stations, only a small reduction of 1,5-bisphosphate carboxylase (Rubisco) activity was found [53]. In summary, comparing out results with past studies, it is clear that assays of beam damage as done by Chl fluorescence kinetics in the current work

Table $9 \mathrm{Zn}$ concentrantions in the leaves in positions 0-4 from top to bottom with 0: rosette and 4: mature leaf, sampled from three plants

\begin{tabular}{|c|c|c|c|c|c|c|c|c|}
\hline Sample & $\begin{array}{l}\text { Pos } 0 \\
\mu X R F \\
{\left[\mathrm{mg} \mathrm{kg}^{-1}\right]}\end{array}$ & $\begin{array}{l}\text { Pos } 0 \\
\text { ICPMS } \\
{\left[\mathrm{mg} \mathrm{kg}^{-1}\right]}\end{array}$ & $\begin{array}{l}\text { Pos } 1 \\
\mu X R F \\
{\left[\mathrm{mg} \mathrm{kg}^{-1}\right]}\end{array}$ & $\begin{array}{l}\text { Pos } 1 \\
\text { ICPMS } \\
{\left[\mathrm{mg} \mathrm{kg}^{-1}\right]}\end{array}$ & $\begin{array}{l}\text { Pos } 2 \text { and } 3 \\
\mu X R F \\
{\left[\mathrm{mg} \mathrm{kg}^{-1}\right]}\end{array}$ & $\begin{array}{l}\text { Pos } 2 \text { and } 3 \\
\text { ICPMS } \\
{\left[\mathrm{mg} \mathrm{kg}^{-1}\right]}\end{array}$ & $\begin{array}{l}\text { Pos } 4 \\
\mu X R F \\
{\left[\mathrm{mg} \mathrm{kg}^{-1}\right]}\end{array}$ & $\begin{array}{l}\text { Pos } 4 \\
\text { ICPMS } \\
{\left[\mathrm{mg} \mathrm{kg}^{-1}\right]}\end{array}$ \\
\hline Mean & 2840 & 3181 & 2271 & 2763 & 3496 & 3453 & 7838 & 4250 \\
\hline Standard error & 345 & 615 & 245 & 980 & 308 & 503 & 1438 & 872 \\
\hline RSE \% & 5.66 & & 9.77 & & 0.62 & & 29.68 & \\
\hline
\end{tabular}

Please note that the same leaves were used for $\mu$ XRF and ICP-MS, but entire leaves were digested for ICP-MS, not only the area on them that was measured by $\mu$ XRF. These values are corrected to match the difference in mass between the fresh leaves in $\mu$ XRF with dry mass in ICPMS. The relative standard error percentage (SE/ mean $\%$, with $n=2$ and SE $=$ STDEV/sqrt(n)) shows the difference between the $\mu$ XRF result and the ICP-MS 


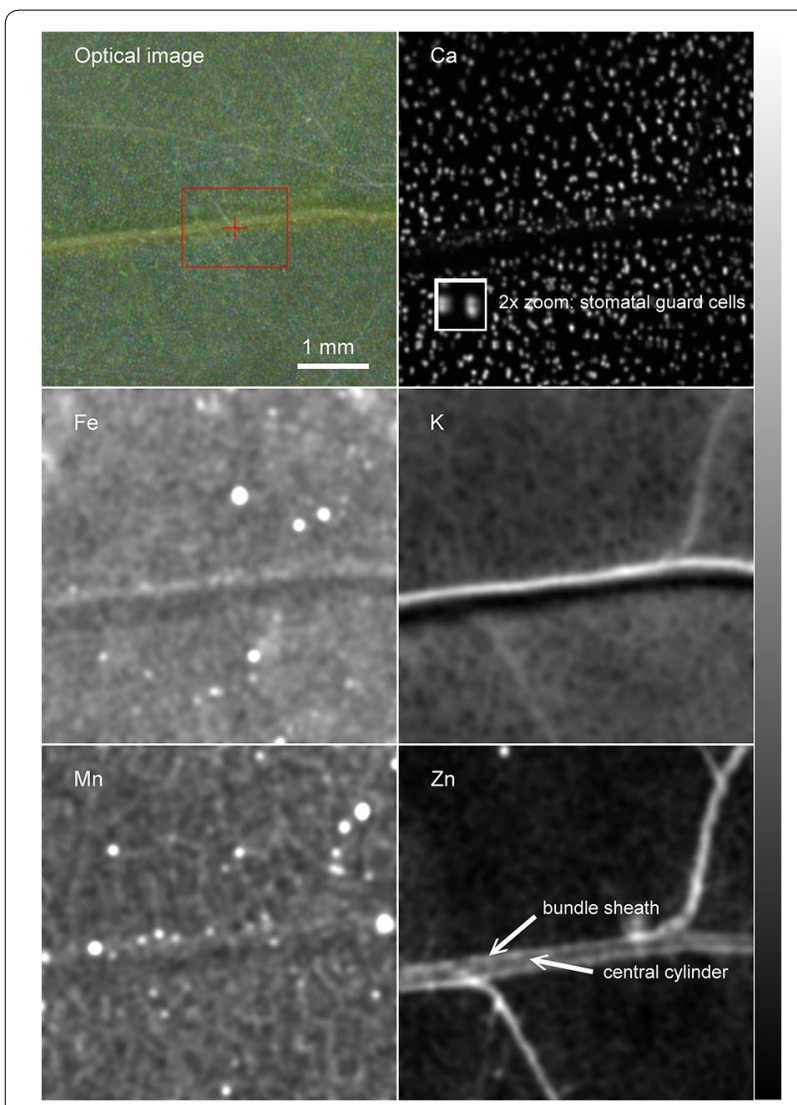

Fig. 8 Metal distribution in a pepper leaf (C. annuum, cultivar 'Kozy Roh'). The leaf was measured in a single cycle with 600 ms integration time per point and $15 \mu \mathrm{m}$ point distance. Measured with He atmosphere in the hutch but air in the measuring chamber. Maps of photosynthetic parameters for the same leaf before and after radiation are shown in Fig. 5. Gaussian smoothing was applied to all element maps (sigma $=1$ for $\mathrm{Ca}$, sigma $=3$ for all other elements). The element maps of this figure are semi-quantitative $(0=$ black, maximum $=$ white), obtained by spectral deconvolution but without normalization to a standard. Images are then in detector counts instead of concentration units. The zoomed image of the Ca map shows the epidermal guard cells, which are known to contain high $\mathrm{Ca}$, confirming the high resolution of the $\mu \mathrm{XRF}$ measurement

are crucial for verifying that X-ray exposure of plants does not damage these study subjects too much.

4. In terms of metal localization, we demonstrate that a benchtop system is able to yield high-resolution maps of micronutrients in intact leaves and roots of non-accumulator crop plants (pepper and soybean). The achieved spatial resolution is enough to provide information of metal distribution on the tissue level, and in some cases even individual cells can be seen. In leaves, for example, it can show the metal distribution inside trichomes, the $\mathrm{Ca}$ accumulation in stomatal guard cells, the $\mathrm{Zn}$ accumulation in epidermal metal storage cells and the bundle sheath of veins. This vastly extends the application of the system in plant research, because not all processes of metal uptake, translocation and sequestration studied in hyperaccumulator plants can be directly related to non-hyperaccumulators. In earlier systems, researchers tried to overcome the sensitivity limitation by immersing roots in extremely high trace metal concentrations, $900 \mu \mathrm{mol} \mathrm{L}^{-1}$ each for Fe and Mn [22]. Such concentrations never occur in vivo and are well-known to be highly toxic, so that the value of such measurements was highly questionable. With the current system, in contrast, plant nutrition and sublethal toxicity can be measured under fully realistic growth conditions. This is decisive for the use of such systems in plant breeding, assessment of the quality and safety of food, as well as environmental studies. Subcellular resolution can only be attained at a nanoprobe beamline in a 3rd generation synchrotron [54]. This cannot be done in vivo, due to the strong radiation damage, and it requires shock frozen samples [55]. Therefore, only a benchtop system as shown here near to suitable cultivation facilities allows for direct comparison of element distribution in tissues with other physiological parameters, e.g. photosynthesis. Further, in many cases it is impossible to know when preparing a synchrotron sample which part of a larger plant organ like a leaf is actually representative for the whole organ, or which part is the most interesting in terms of metal distribution. Here, a benchtop system can provide the information that is necessary for an informed decision.

Due to the lower metal content in roots than in leaves, imaging of metal distribution in roots has been done using synchrotron radiation (see Table 6 in review of de

(See figure on next page.)

Fig. 9 Metal distribution in a root of soybean (G. max, cultivar 'Galina'). a Tip of the lateral roots. The root was measured 120 times (cycles) by summing up the counts for each pixel, each cycle with $6 \mathrm{~ms}$ integration time per point and point distance of $8 \mu \mathrm{m}$. The machine enclosure had a He atmosphere but measuring chamber was with air to keep the root alive. Gaussian smoothing was applied to all element maps (sigma = 3 for all elements). b Older part of the same lateral root with an emerging root hair. This was measured with 80 cycles, each with 6 ms integration time per point and $4 \mu \mathrm{m}$ point distance. Gaussian smoothing was applied to all element maps (sigma $=3$ for all elements). The element maps of this figure are semi-quantitative, obtained by spectral deconvolution but without normalization to a standard. Images are in detector counts instead of concentration units 


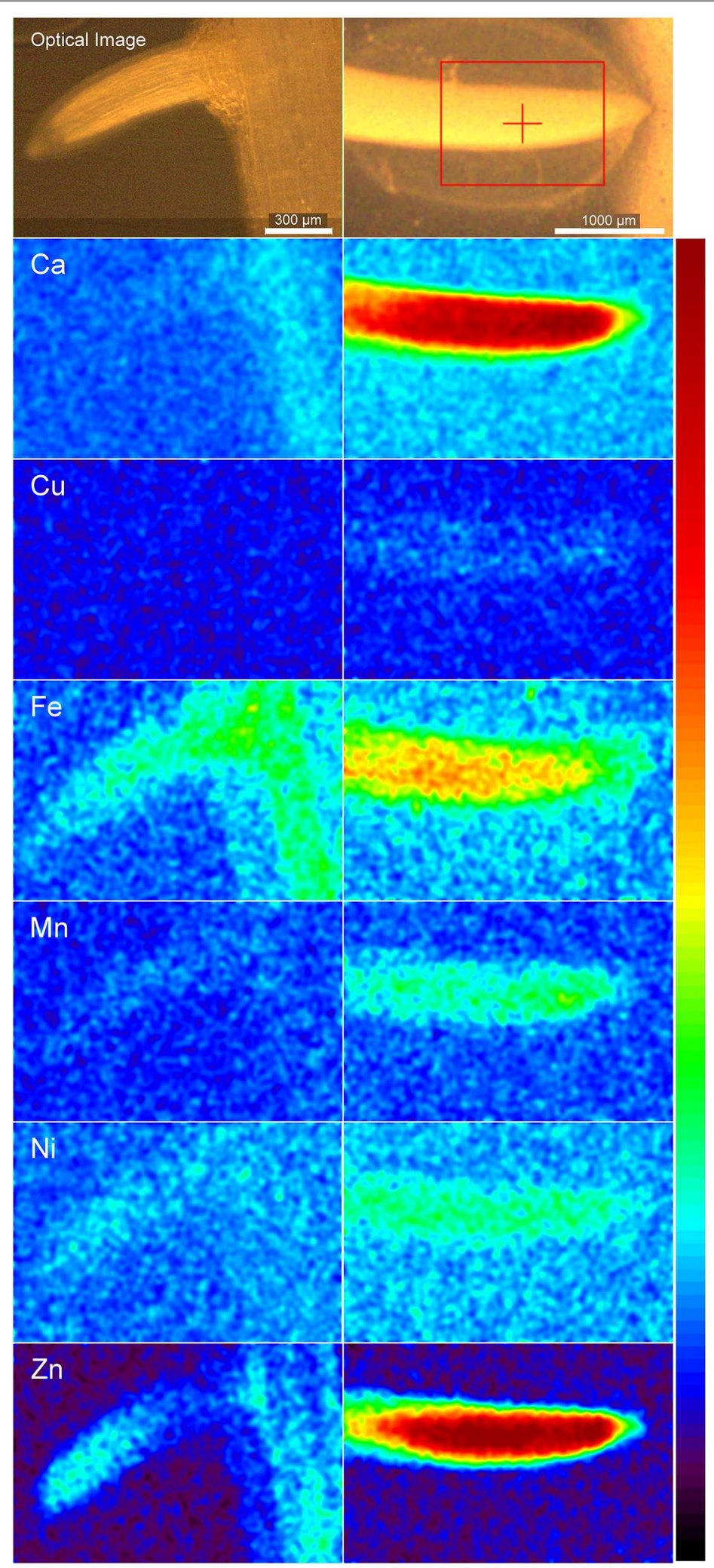


Carvalho et al. [56], and review of Kopittke et al. [57]) but not with benchtop machines. For example, using 2D scans with synchrotron light with a beam size of $10 \times 7 \mu \mathrm{m}$, Sarret et al. [58] studied the metal distribution in mycorrhized roots of tomato grown in heavily polluted soil. $\mathrm{Zn}$ and $\mathrm{Cu}$ were highly concentrated in the whole root while $\mathrm{Fe}$ and $\mathrm{Mn}$ were more concentrated at the surface of the root. All four elements were in high concentration at the fungal filaments. Using synchrotron microtomography with resolution $15-20 \mu \mathrm{m}$, Terzano et al. [59] found that $\mathrm{Zn}$ in roots of rocket plants grown on compost amended soil is mainly in the endodermis and xylem vessels, while plants grown in untreated soils showed a more homogeneous $\mathrm{Zn}$ distribution. However, soils were artificially polluted with very high amounts of $\mathrm{Zn}\left(0.1 \mathrm{~mol} \mathrm{~L}^{-1}\right)$. The level of resolution achieved in these synchrotron works on crop plants, scanning areas in the millimetre range, compares well with the results of this work with a benchtop machine for hydroponics plants treated with $100 \mu \mathrm{mol} \mathrm{L}^{-1} \mathrm{Zn}$.

The polycapillary optics has the best transmission properties in the region of the K-edges of the transition metals at about $9 \mathrm{keV}$ [37]. The bremsstrahlung radiation


thick leaves, with different layers of cells getting a different excitation profile. However, X-rays have a longer penetration depth than electrons. With water as the main element in the matrix of biological samples, and an excitation spectrum mainly due to $\mathrm{Rh} K \alpha$, and the bremsstrahlung tail that is filtered in the transition metals K-edge region, it is expected that the epidermis cells contribute the most to the image. For heavier elements like $\mathrm{Zn}$, also the deeper layers of the leaf are completely penetrated, while for light elements like $\mathrm{Ca}$ the $\mathrm{X}$-ray fluorescence from deeper layers becomes highly attenuated.

For the spatial resolution both the step size and counting time have an influence. Manufacturer's test with the Siemens star Cr map shows that $5 \mu \mathrm{m}$ step with $50 \mathrm{~ms}$ accurately reproduces the star in high resolution [60]. Plant samples have much lower concentrations, for which we used from $720 \mathrm{~ms}$ integration time per pixel for the lowest concentrations in non-accumulators to $3 \mathrm{~ms}$ for the highest concentration samples in hyperaccumulators. Oversampling further improved the visualization of low concentration elements as the density of scanning lines was increased $4 \times$, i.e. the same area was scanned $4 x$ longer. In the current study this strategy was successfully applied as single cycle scanning for the A. halleri trichomes and as multi-cycle scanning for the soybean roots. The advantage of measuring a single low speed cycle compared to measuring many cycles with higher stage speed is the complete removal of artefacts that occur when a living sample slightly changes shape during the measurement e.g. due to growth processes or movement.

When comparing the collection times with those of electron microscopy (like EDX) it should be kept in mind that the X-ray fluorescence at the energies of the K- edges of transition metals and lighter elements is less efficient than Auger electrons due to the lower yield for fluorescence [61]. Detection limits of XRF, however, are better than for EDX because no bremsstrahlung background is generated in the sample, and the bremsstrahlung generated in the X-ray tube can be removed by primary emission filters, leading to the trace element sensitivity shown in the current work. Further, the problem of long collection times of XRF can be amended with large-area detectors, as done in the current work.

Plant leaves and roots are objects with inhomogeneous surface. Flattening of very curvy leaves like in $N$. caerulescens is not always possible without damage, and trichomes like on $A$. halleri leaves cannot be flattened anyhow. Mounting over a layer of perforated print foil or perforated polycarbonate thin layer, improved the flatness of the specimen. However, moving the specimen out of focus up to the hundredths of microns gave a variation in concentration of about $10 \%$ for homogeneous areas. The most significant loss might be of resolution of features on the specimen like trichomes, which was tested with $A$. halleri leaves, and showed surprisingly low defocussing of the $\mu$ XRF maps. The excitation of the sample from an angle, however, led to an optical shift of out-offocus parts of the sample, in effect leading to a distortion of the map. This has to be kept in mind when comparing element localizations on non-flat samples.

We observed high variability in $\mathrm{Zn}$ content between the leaves of the same development stage of $N$. caerulescens (Table 9). In this context it is important to mention that the empirical standard should match the thickness of the leaf to yield a correct quantification. A lower count rate at a thinner area may be accounted as having a lower concentration. Therefore, different standards are needed and were used for mature vs. young leaves.

Both the certified liquid standard (Table 3), and the laboratory-made liquid and foil standards mimicking the carbon composition of the leaf samples (Tables 4, 6 and 7), validated the elemental concentration determination. The relative standard error percentage (RSE \%) in the certified standard (Table 3) showed that for elements in a concentration above the LOD (several tenths mg $\mathrm{kg}^{-1}$, see Table 8) the RSE \% was below $10 \%$. The laboratory-made standards furthemore provided a reasonable approximation to the metal distribution content for elements within the LODs (Tables 6 and 8 for the LODs). For $\mathrm{Ca}$ and $\mathrm{K}$ the higher RSE \% may be linked to 
the background-related difficulties in measuring them in ICP-MS.

The LOD shows higher values for the lab made foil standards. In the case of $\mathrm{K}$ and $\mathrm{Ca}$, the sensitivity could be increased by increasing the net counts when measuring in He atmosphere instead of air.

The highest $\mathrm{Zn}$ content was detected in the oldest mature leaves (development stage 4 ) at the base of the rosette (about 3 times higher that of the youngest leaves). In a previous extensive study [20] the amount of $\mathrm{Zn}$ in young and mature leaves of $N$. caerulescens was similar in young plants under $100 \mu \mathrm{mol} \mathrm{L}{ }^{-1} \mathrm{Zn}$, and the same was observed here for development stages $\mathbf{0}-\mathbf{3}$. It should be considered that ICP-MS gives the total metal concentration in the leaf after digestion. Apart from that, the total metal concentration can be different from the concentrations determined by the microfluorescence considering distribution variability within a leaf. This uneven distribution is particularly visible in hyperaccumulator plants, where even a high $\mathrm{Zn}$ concentration at the rim of the leaves can be found (Fig. 7). Older leaves show a more homogeneous $\mathrm{Zn}$ distribution than younger leaves, maybe as a result of reaching a threshold for accumulation in the tip, with all subsequent metal being accumulated in the rest of the blade.

\section{Conclusions}

The work shows that an optimized benchtop machine can be used for analyses of the metal distribution in plants in vivo. Together with appropriate quantification methods, it allows determination of metal distribution and quantification in a reliable manner in intact, living plant leaves and roots with a sensitivity of a tenths of $\mathrm{mg} \mathrm{kg}{ }^{-1}$ and a space resolution down to about $15 \mu \mathrm{m}$. The spatial resolution achievable is enough to provide information of metal distribution on the tissue level, and in some cases even in individual cells. In the leaves we showed $\mathrm{Ca}$ accumulation in stomatal guard cells, $\mathrm{Zn}$ accumulation in epidermal metal storage cells and the bundle sheath of veins, and $\mathrm{Ca}$ and $\mathrm{Zn}$ distribution in trichomes. Truly non-destructive in vivo measurement of micronutrients became possible not only by the optimization of the $\mu \mathrm{XRF}$ machine itself, but also by the construction of a measuring chamber in which plant organs like leaves or roots can be kept in physiological conditions throughout long measurements. With this chamber, it became furthermore possible to correlate element distribution of the specimen with maps of parameters of photosynthesis via fluorescence kinetic measurements, which demonstrated high sample vitality even after a long X-ray irradiation (up to $20 \mathrm{~h}$ measurements for the entire specimen, up to $600 \mathrm{~ms}$ per spot) needed to obtain the micronutrient distribution in non-accumulator plant.
The long counting time disadvantage is surpassed by the possibility to measure the specimen at any growth stage and being able to measure a number of replicates, both impossible to achieve in a synchrotron where beamtime is limited. In summary, the optimised benchtop machine opens the possibility to measure in the laboratory micronutrient distribution along the plant growth cycle and in response to abiotic and biotic stress.

\section{Supplementary information}

Supplementary information accompanies this paper at https://doi. org/10.1186/s13007-020-00621-5.

Additional file 1: Figure S1. Scheme of the sample mounting in the measuring chamber for both the $\mu \mathrm{XRF}$ and chlorophyll fluorescence kinetics measurements. The specimen is gently pressed against a printer foil window with a cotton pad (to avoid damage) and a 3-D printed polycarbonate plate to keep the specimen straight. A nylon mesh is used to press everything against the window by fixing it with an O-ring around the cover lid rim. The holes grid in the polycarbonate plate and the permeability of fine nylon mesh ensures the supply of air and humidity to the specimen

Additional file 2: Figure S2. Chlorophyll fluorescence kinetic measurements of a pepper leaf. The intensity of the supersaturating flashes was $3500 \mu \mathrm{mol} \mathrm{m} \mathrm{m}^{-2} \mathrm{~s}^{-1}$ and actinic light was $100 \mu \mathrm{mol} \mathrm{m} \mathrm{m}^{-2} \mathrm{~s}^{-1}$. Intensities of $\mathrm{F}_{0}$ (minimal $\mathrm{Chl}$ fluorescence of the dark-adapted leaf). Fm (maximal Chl

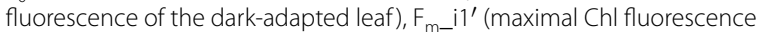
under actinic light at the irradiance phase 1 ) and $\mathrm{F}_{0 \_} \mathrm{i}^{\prime}{ }^{\prime}$ (minimal $\mathrm{Chl}$ fluorescence under actinic light at the irradiance phase 1) were used to calculate operating efficiency of PSII $\left(\Phi_{\mathrm{PS} \|}=\left(\mathrm{F}_{\mathrm{m}}^{\prime}-\mathrm{F}_{0}^{\prime}\right) / \mathrm{F}_{\mathrm{m}}^{\prime}\right)$ and complete non-photochemical quenching $\left(\mathrm{NPQ}=\left(\mathrm{F}_{\mathrm{m}}-\mathrm{F}_{\mathrm{m}}^{\prime}\right) / \mathrm{F}_{\mathrm{m}}^{\prime}\right)$.

Additional file 3: Figure S3. Calculation of the incoming flux generated by the Rh X-ray tube operating at $50 \mathrm{kV}$ and $600 \mu \mathrm{A}$, in air, with primary emission filter Al $100 \mu \mathrm{m} \mid \mathrm{Ti} 25 \mu \mathrm{m}$, in the $\mu$ XRF measurements. (a) Spectrum in linear scale, (b) Spectrum in log scale, (c) distribution by energy region.

Additional file 4: Figure S4. The effect of the multilayer mask on the detectors of the $\mu \mathrm{XRF}$ machine, to reduce spurious counts of $\mathrm{Ni}$, $\mathrm{Cu}$ and $\mathrm{Zn}$ : (a) The spectrum for the blank, i.e. scatter on the plexiglass table. The mask eliminates almost all spurious counts from $\mathrm{Zn}$ and $\mathrm{Cu}$, and most of $\mathrm{Ni}$. (b) Spectrum of a pepper (Capsicum annuum) leaf measured with and without the mask, demonstrating that the mask only diminished the spurious counts but not the true signal from the sample.

Additional file 5: Figure S5. Assessing the space resolution of the $\mu$ XRF measurements: scanning of the edge of a $30 \mu \mathrm{m}$ thick Al foil with and without an Al-Ti primary emission filter.

Additional file 6: Table S1. Metal concentrations from ICP-MS for crop plants: pepper leaf (C. annuum, cultivar 'Kozy Roh') and soybean roots (G. max, cultivar 'Galina'). Data for the pepper were collected from leaves of the same age and the same plants as the leaves used for the $\mu$ XRF studies, though not the same leaves. Root data were obtained from a pooled, homogenized sample of four plants. The values represent averages $\pm \mathrm{SE}$.

\section{Abbreviations}

$\mu$ XRF: Micro X-ray fluorescence; ddH2O: Double distilled water; EDX: Energy dispersive $X$-ray analysis; EDXMA: Energy dispersive X-ray microanalysis; FWHM: Full width at half maximum of the peak; HHNS: Hyperaccumulator hydroponic nutrient solution; ICP-MS: Inductively coupled plasma mass spectrometry; ICP-sfMS: Inductively coupled sector field plasma mass spectrometry; LA-ICPMS: Laser ablation-inductively coupled plasma mass spectrometry; LOD: Limit of detection; OCR: Output count rate; OJIP: In vivo fluorescence rise from the initial state with open reaction centres $(O)$ via reduction of plastoquinone $A(J)$ and $B(I)$ to reduction of the plastoquinone pool (P) [48]; PFA: Perfluoroalkoxy 
alkanes; PSI: Photosystem I; PSII: Photosystem II; PTFE: Polytetrafluoroethylene; RSE \%: Relative standard error percentage.

\section{Acknowledgements}

The authors are most grateful to Bojan Vujic for 3D-printing several accessories for this work, such as the grid-plate for aiding the leaf mounting and the grid for casting the foil standards. Bojan Vujic, Dr. Noelia Jaime Perez and Dr. Archana Mishra are thanked for help with cultivation of N. caerulescens. Dr. Falk Reinhardt, Dr. Max Bügler, and Dr. Thorsten Ahner from BRUKER Nano GmbH are acknowledged for help with Xmethod and the machine upgrade. Dr. Ulrich Waldschläger from BRUKER Nano GmbH is acknowledged for engineering work for the detector shielding of the machine upgrade. The authors are grateful for funding from the Ministry of Education, Youth and Sports of the Czech Republic with co-financing from the European Union (Grant "KOROLID", CZ.02.1.01/0.0/0.0/15_003/0000336) and the Czech Academy of Sciences (RVO: 60077344).

\section{Authors' contributions}

HK initiated and supervised the project, chose the configuration of the $\mu$ XRF machine, constructed the measuring chamber and made the foil standards. HK did the $\mu$ XRF measurements on soybean, pepper, and A. halleri and grew the latter two species. AM did the N. caerulescens experiment, the $\mu$ XRF measurements on $N$. caerulescens and standards and quantified the $\mu$ XRF data. FM conducted the photosynthesis measurements and performed the soybean experiment. NB did the ICP-MS measurements. TW calculated the primary beam intensity on the sample. AM, HK and FM wrote the manuscript. All authors reviewed the manuscript and agree with the submitted version of the manuscript. All authors read and approved the final manuscript.

\section{Funding}

Ministry of Education, Youth and Sports of the Czech Republic with cofinancing from the European Union (Grant "KOROLID", CZ.02.1.01/0.0/0.0/15_0 03/0000336) and the Czech Academy of Sciences (RVO: 60077344).

\section{Availability of data and materials}

All data generated or analysed during this study are included in this published article and its additional files.

\section{Ethics approval and consent to participate}

Not applicable.

\section{Consent for publication}

Not applicable.

\section{Competing interests}

The authors declare that they have no competing interests.

\section{Author details}

${ }^{1}$ Biology Centre of the Czech Academy of Sciences, Department of Plant Biophysics \& Biochemistry, Institute of Plant Molecular Biology, Branišovská 1160/31, 37005 Ceske Budejovice, Czech Republic. ${ }^{2}$ Bruker Nano GmbH, Am Studio 2D, 12489 Berlin, Germany. ${ }^{3}$ Department of Experimental Plant Biology, University of South Bohemia, Branišovská 1160/31, 37005 Ceske Budejovice, Czech Republic.

Received: 30 November 2019 Accepted: 23 May 2020

Published online: 08 June 2020

\section{References}

1. Marschner P. Marschner's mineral nutrition of higher plants. 3rd ed. Amsterdam: Elsevier; 2012.

2. Andresen $\mathrm{E}$, Peiter $\mathrm{E}$, Küpper H. Trace metal metabolism in plants. J Exp Bot. 2018;69:909-54.

3. Yruela I. Transition metals in plant photosynthesis. Metallomics. 2013;5:1090-109.

4. Aznar A, Chen NWG, Thomine S, Dellagi A. Immunity to plant pathogens and iron homeostasis. Plant Sci. 2015;240:90-7.

5. Küpper $\mathrm{H}$, Andresen E. Mechanisms of metal toxicity in plants. Metallomics. 2016;8:269-85.
6. Baker AJ, Walker P. Ecophysiology of metal uptake by tolerant plants. Heavy metal tolerance in plants: evolutionary aspects. Boca Raton: CRC Press; 1990. p. 155-77.

7. Leitenmaier B, Küpper H. Compartmentation and complexation of metals in hyperaccumulator plants. Front Plant Sci. 2013;4:374.

8. Walker DJ, Bernal MP. The effects of copper and lead on growth and zinc accumulation of Thlaspi caerulescens J. and C. Presl: implications for phytoremediation of contaminated Soils. Water Air Soil Pollut. 2004;151:361-72.

9. Mijovilovich A, Leitenmaier B, Meyer-Klaucke W, Kroneck PMH, Gotz B, Küpper H. Complexation and toxicity of copper in higher plants. II. Different mechanisms for copper versus cadmium detoxification in the copper-sensitive cadmium/zinc hyperaccumulator Thlaspi caerulescens (Ganges ecotype). Plant Physiol. 2009;151:715-31.

10. Küpper H, Mijovilovich A, Meyer-Klaucke W, Kroneck PMH. Tissue- and age-dependent differences in the complexation of cadmium and zinc in the cadmium/zinc hyperaccumulator Thlaspi caerulescens (Ganges ecotype) revealed by X-ray absorption spectroscopy. Plant Physiol. 2004;134:748-57.

11. Martens SN, Boyd RS. The ecological significance of nickel hyperaccumulation: a plant chemical defense. Oecologia. 1994;98:379-84.

12. Boyd RS, Martens SN. Nickel hyperaccumulated by Thlaspi montanum var. montanum is acutely toxic to an insect herbivore. Oikos. 1994;70:21-5.

13. Jhee EM, Boyd RS, Eubanks MD. Nickel hyperaccumulation as an elemental defense of Streptanthus polygaloides (Brassicaceae): influence of herbivore feeding mode. New Phytol. 2005;168:331-44.

14. Kazemi-Dinan A, Barwinski A, Stein RJ, Krämer U, Müller C. Metal hyperaccumulation in Brassicaceae mediates defense against herbivores in the field and improves growth. Entomol Exp Appl. 2015;157:3-10.

15. Stolpe C, Krämer U, Müller C. Heavy metal (hyper)accumulation in leaves of Arabidopsis halleri is accompanied by a reduced performance of herbivores and shifts in leaf glucosinolate and element concentrations. Environ Exp Bot. 2017;133:78-86.

16. Zhao F-J, Moore KL, Lombi E, Zhu Y-G. Imaging element distribution and speciation in plant cells. Trends Plant Sci. 2014;19:183-92.

17. van der Ent A, Przybylowicz WJ, de Jonge MD, Harris HH, Ryan CG, Tylko G, Paterson DJ, Barnabas AD, Kopittke PM, Mesjasz-Przybylowicz J. X-ray elemental mapping techniques for elucidating the ecophysiology of hyperaccumulator plants. New Phytol. 2018;218:432-52.

18. Küpper H, Zhao FJ, McGrath SP. Cellular compartmentation of zinc in leaves of the hyperaccumulator Thlaspi caerulescens. Plant Physiol. 1999:119:305-11.

19. Cosio C, DeSantis L, Frey B, Diallo S, Keller C. Distribution of cadmium in leaves of Thlaspicaerulescens. J Exp Bot. 2005;56:765-75.

20. Küpper H, Kochian LV. Transcriptional regulation of metal transport genes and mineral nutrition during acclimatization to cadmium and zinc in the $\mathrm{Cd} / \mathrm{Zn}$ hyperaccumulator, Thlaspi caerulescens (Ganges population). New Phytol. 2010;185:114-29.

21. Krämer U. Conceptualizing plant systems evolution. Curr Opin Plant Biol. 2018;42:66-75.

22. Rodrigues ES, Gomes MHF, Duran NM, Cassanji JGB, da Cruz TNM, Sant'Anna Neto A, Savassa SM, de Almeida E, Carvalho HWP. Laboratory microprobe $X$-ray fluorescence in plant science: emerging applications and case studies. Front Plant Sci. 2018;9:1588.

23. Ramos I, Pataco IM, Mourinho MP, Lidon F, Reboredo F, Pessoa MF, Carvalho ML, Santos JP, Guerra M. Elemental mapping of biofortified wheat grains using micro X-ray fluorescence. Spectrochim Acta Part B At Spectrosc. 2016;120:30-6.

24. Fittschen UEA, Kunz H-H, Höhner R, Tyssebotn IMB, Fittschen A. A new micro X-ray fluorescence spectrometer for in vivo elemental analysis in plants. X-Ray Spectrom. 2017;46:374-81.

25. Küpper H, Parameswaran A, Leitenmaier B, Trtilek M, Setlik I. Cadmiuminduced inhibition of photosynthesis and long-term acclimation to cadmium stress in the hyperaccumulator Thlaspi caerulescens. New Phytol. 2007;175:655-74.

26. Graham TL. Flavonoid and isoflavonoid distribution in developing soybean seedling tissues and in seed and root exudates. Plant Physiol. 1991;95:594-603.

27. Zhao F, McGrath SP, Crosland AR. Comparison of three wet digestion methods for the determination of plant sulphur by inductively coupled 
plasma atomic emission spectroscopy (ICP-AES). Commun Soil Sci Plant Anal. 1994;25:407-18.

28. Andresen E, Opitz J, Thomas G, Stärk HJ, Dienemann H, Jenemann K, Dickinson $B C$, Küpper $\mathrm{H}$. Effects of $\mathrm{Cd} \&$ Ni toxicity to Ceratophyllum demersum under environmentally relevant conditions in soft \& hard water including a German lake. Aquat Toxicol. 2013;142:387-402.

29. Thomas G, Andresen E, Mattusch J, Hubáček T, Küpper H. Deficiency and toxicity of nanomolar copper in low irradiance - a physiological and metalloproteomic study in the aquatic plant Ceratophyllum demersum. Aquat Toxicol. 2016;177:226-36.

30. Genty B, Briantais JM, Baker NR. The relationship between the quantum yield of photosynthetic electron transport and quenching of chlorophyll fluorescence. Biochim Biophys Acta. 1989;990:87-92.

31. Baker NR. Chlorophyll fluorescence: a probe of photosynthesis in vivo. Annu Rev Plant Biol. 2008;59:89-113.

32. Maxwell K, Johnson GN. Chlorophyll fluorescence-a practical guide. J Exp Bot. 2000;51:659-68.

33. Stirbet A, Govindjee. On the relation between the Kautsky effect (chlorophyll a fluorescence induction) and photosystem II: basics and applications of the OJIP fluorescence transient. J Photochem Photobiol B Biol. 2011;104:236-57.

34. Küpper H, Benedikty Z, Morina F, Andresen E, Mishra A, Trtílek M. Analysis of OJIP chlorophyll fluorescence kinetics and QA reoxidation kinetics by direct fast imaging. Plant Physiol. 2019;179:369-81.

35. Kalaji HM, Schansker G, Ladle RJ, Goltsev V, Bosa K, Allakhverdiev SI, Brestic M, Bussotti F, Calatayud A, Dąbrowski P, Elsheery NI. Frequently asked questions about in vivo chlorophyll fluorescence: practical issues. Photosynth Res. 2014;122:121-58.

36. Thompson A, Attwood D, Gullikson E, Howells E, Kim K-J, Kirz J, Kortright J, Lindau I, Liu Y, Pianetta P, Robinson A, Scofield J, Underwood J, Williams G, Winick H. X-ray data booklet. Berkeley: Center for X-ray Optics and Advanced Light Source; 2009

37. WolffT, Mantouvalou I, Malzer W, Nissen J, Berger D, Zizak I, Sokaras D, Karydas A, Grlj N, Pelicon P, Schütz R, Žitnik M, Kanngießer B. Performance of a polycapillary halflens as focussing and collecting optic-a comparison. J Anal At Spectrom. 2009;24:669-75.

38. Wolff T, Malzer W, Mantouvalou I, Hahn O, Kanngießer B. A new fundamental parameter based calibration procedure for micro X-ray fluorescence spectrometers. Spectrochim Acta Part B At Spectrosc. 2011;66:170-8

39. BRUKER. The details of the multilayer are proprietary knowledge of BRUKER.

40. BRUKER. Webinar. Different approaches to bulk quantification. Bruker Nano Analytics, Berlin, Germany Webinar, June 01, 2017. https://www. bruker.com/fileadmin/user_upload/8-PDF-Docs/X-rayDiffraction_Eleme ntalAnalysis/mXRF/Webinars/Bruker_MXRF_wbnr-M4_Bulk-Quantifica tion_20170601.pdf.

41. Kozhevnikova AD, Seregin IV, Gosti F, Schat H. Zinc accumulation and distribution over tissues in Noccaea caerulescens in nature and in hydroponics: a comparison. Plant Soil. 2017:411:5-16.

42. Schindelin J, Arganda-Carreras I, Frise E, Kaynig V, Longair M, Pietzsch T, Preibisch S, Rueden C, Saalfeld S, Schmid B, Tinevez JY, White DJ, Hartenstein V, Eliceiri K, Tomancak P, Cardona A. Fiji: an open-source platform for biological-image analysis. Nat Methods. 2012;9:676-82.

43. MacFarland TW, Yates JM. Mann-whitney u test. Introduction to nonparametric statistics for the biological sciences using R. Cham: Springer; 2016. p. 103-32.

44. Küpper H, Lombi E, Zhao FJ, McGrath SP. Cellular compartmentation of cadmium and zinc in relation to other elements in the hyperaccumulator Arabidopsis halleri. Planta. 2000;212:75-84.

45. Weigend M, Mustafa A, Ensikat H-J. Calcium phosphate in plant trichomes: the overlooked biomineral. Planta. 2018:247:277-85.
46. Mishra S, Wellenreuther G, Mattusch J, Stärk H-J, Küpper H. Speciation and distribution of arsenic in the nonhyperaccumulator macrophyte Ceratophyllum demersum. Plant Physiol. 2013;163:1396-408.

47. International Union of Pure and Applied Chemistry. Nomenclature, symbols, units and their usage in spectrochemical analysis- II. Data interpretation. Pure Appl Chem. 1976;45:99-103.

48. Küpper H, Lombi E, Zhao FJ, Wieshammer G, McGrath SP. Cellular compartmentation of nickel in the hyperaccumulators Alyssum lesbiacum, Alyssum bertolonii and Thlaspigoesingense. J Exp Bot. 2001;52:2291-300

49. Callahan DL, Hare DJ, Bishop DP, Doble PA, Roessner U. Elemental imaging of leaves from the metal hyperaccumulating plant Noccaea caerulescens shows different spatial distribution of $\mathrm{Ni}, \mathrm{Zn}$ and $\mathrm{Cd}$. RSC Adv. 2016;6:2337-44.

50. Matsushima U, GrafW, Zabler S, Manke I, Dawson M, Choinka G, Hilger A, Herppich WB. 3D-analysis of plant microstructures: advantages and limitations of synchrotron X-ray microtomography. Int Agrophys. 2013;27:23-30.

51. Petruzzellis F, Pagliarani C, Savi T, Losso A, Cavalletto S, Tromba G, Dullin C, Bär A, Ganthaler A, Miotto A, Mayr S, Zwieniecki MA, Nardini A, Secchi F. The pitfalls of in vivo imaging techniques: evidence for cellular damage caused by synchrotron X-ray computed micro-tomography. New Phyrol. 2018:220:104-10.

52. Stevens SE, Simic MG, Rao VSK. X-Ray induced inactivation of the capacity for photosynthetic oxygen evolution and nitrate reduction in blue-green Algae. Radiat Res. 1975;63:395.

53. Arena C, De Micco V, Aronne G, Pugliese M, Virzo De Santo A, De Maio A. Response of Phaseolus vulgaris $L$. plants to low-let ionizing radiation: growth and oxidative stress. Acta Astronaut. 2013;91:107-14.

54. Mijovilovich A, Mishra A, Brückner D, Spiers K, Andresen E, Garrevoet J, Falkenberg G, Küpper H. MicroX-ray absorption near edge structure tomography reveals cell-specific changes of $Z n$ ligands in leaves of turnip yellow mosaic virus infected plants. Spectrochim Acta B. 2019;157:53-62.

55. Strange RW, Feiters MC. Biological X-ray absorption spectroscopy (BioXAS): a valuable tool for the study of trace elements in the life sciences. Curr Opin Struct Biol. 2008;18:609-16.

56. de Carvalho GG, Bueno Guerra MB, Adame A, Nomura CS, Oliveira PV, de Carvalho HW, Santos D, Nunes LC, Krug FJ. Recent advances in LIBS and XRF for the analysis of plants. J Anal Atom Spectrom. 2018:33:919-44.

57. Kopittke PM, Punshon T, Paterson DJ, Tappero RV, Wang P, Blamey FPC, van der Ent A, Lombi E. Synchrotron-based X-Ray fluorescence microscopy as a technique for imaging of elements in plants. Plant Physiol. 2018:178:507-23.

58. Sarret G, Schroeder WH, Marcus MA, Geoffroy N, Manceau A. Localization and speciation of $\mathrm{Zn}$ in mycorrhized roots by $\mu \mathrm{SXRF}$ and $\mu$ EXAFS. J Phys IV (Proceedings) EDP Sci. 2003;107:1193-6.

59. Terzano R, Al Chami Z, Vekemans B, Janssens K, Miano T, Ruggiero P. Zinc distribution and speciation within rocket plants (Eruca vesicaria L. Cavalieri) grown on a polluted soil amended with compost as determined by XRF microtomography and Micro-XANES. J Agric Food Chem. 2008:56:3222-31.

60. BRUKER. Lab Report XRF 442. Analytical performance of the M4 TORNADO.

61. Attwood D. Soft X-ray microscopy with diffractive optics. Soft X-Rays Extrem. Ultrav. Radiat. Princ. Appl. Cambridge: Cambridge University Press; 2000

\section{Publisher's Note}

Springer Nature remains neutral with regard to jurisdictional claims in published maps and institutional affiliations. 